\title{
People, dogs and wild game: evidence of human-animal relations from Middle Neolithic burials and personal ornaments in northern Italy
}

\author{
Maria Bernabò Brea', Paola Mazzieri ${ }^{2}$, Roberto Micheli3 \\ 1 Soprintendenza per i Beni Archeologici dell'Emilia Romagna, Museo Archeologico Nazionale di Parma, IT \\ mbernabo@arti.beniculturali.it \\ 2 Scuola di Dottorato in Scienze dell'Antichità - Dottorato in Archeologia, Dipartimento di Scienze Archeologiche, \\ Università degli Studi di Pisa, IT; paolamazzieri@gmail.com \\ 3 Soprintendenza per i Beni Archeologici del Friuli Venezia Giulia, Trieste, IT; roberto.micheli@beniculturali.it
}

\begin{abstract}
In order to review evidence of human-animal relations, the paper offers an overview of the customs and funerary traditions of the Square Mouthed Pottery culture, between c. 5000 and 4300 calBC. We focus on the importance of domestic and wild animals on the basis of an analysis of grave-goods, funerary rites and personal ornaments. We also consider recent discoveries of peculiar offerings of animals and some dog burials. The evidence testifies to a diffusion of a wild component, symbolically emphasising the importance of the hunter identity in a society where subsistence actually depends primarily on domestic animals. Therefore, a contrast is drawn between the everyday and the symbolic worlds.
\end{abstract}

IZVLEČEK - V razpravi predstavljamo odnose med človekom in živalmi, kot se kažejo v pogrebnih običajih in tradicijah kulture 'čašs kvadratnimi ustji' med c. 5000 in 4300 calBC. $S$ pomočjo analiz grobnih pridatkov, osebnega okrasa in pogrebnih ritualov ocenjujemo pomen domačih in divjih živali. Predstavljamo tudi novejša odkritja daritvenih živali in pokope psov. Opazna je komponenta divjega, ki na simbolni ravni poudarja pomen lovske identitete $v$ kontekstu, $v$ katerem prevladuje gospodarjenje z domačimi živalmi. Poudarjen je kontrast med vsakdanjim in simbolnim svetom.

KEY WORDS - burials; personal ornaments; domesticated and wild animals; Square Mouthed Pottery culture; Middle Neolithic

\section{Introduction}

Animal symbolism is an important source for building up culture in almost all human groups; animals are often fundamental symbolic agents in understanding the conception and the representation of the world (Rivera 1999). The distinctive feature of animals is that, being both close to and also remote to people, they can alternate as objects of human thought between metonymy and metaphor. This means that, as symbols, animals have the convenient faculty of representing both existential and normative aspects of human experience, as well as their interrelation (Willis 1974.128).
When Neolithic peoples domesticated plants and animals, they created a category of the wild that had not existed before. The creation of wild-domestic dichotomy had profound consequences for human thought. At the very least, it has been a rich source of metaphors that can be manipulated to many ends in social negotiations (Russell 2002) and during ritual practices. In almost all Neolithic communities, domestic species share the daily space with their masters and often live their life side by side with humans from birth to death, as they are very important elements in subsistence, as sources of food, 
labour, or raw material, and are even able to acquire a real importance in the symbolic domain. However, hunting still has an important role and its significance is particularly related to its symbolic value, since it often confers male identity and status. Such figurative utilization of hunting is a constituent part of the persistent dichotomy existing in many horticultural groups between male/hunting and female/farming (Clastres 1966; Kent 1989; Morris 2000; Descola 2004). Therefore, wild and domestic animals, and activities linked to them, can be perceived as metaphors of the dual gender sphere of human society and the marking of oppositions.

This paper tries to shed light on some of the above issues, giving an account of archaeological evidence from the Middle Neolithic of the central-western Emilia territory in northern Italy. The $5^{\text {th }}$ millennium calBC documents the full development of Neolithic groups and the progressive transformation of their economic and social spheres. The aspects taken into account in this paper reviewing evidence of human-animal relations are those of the customs, the rit-

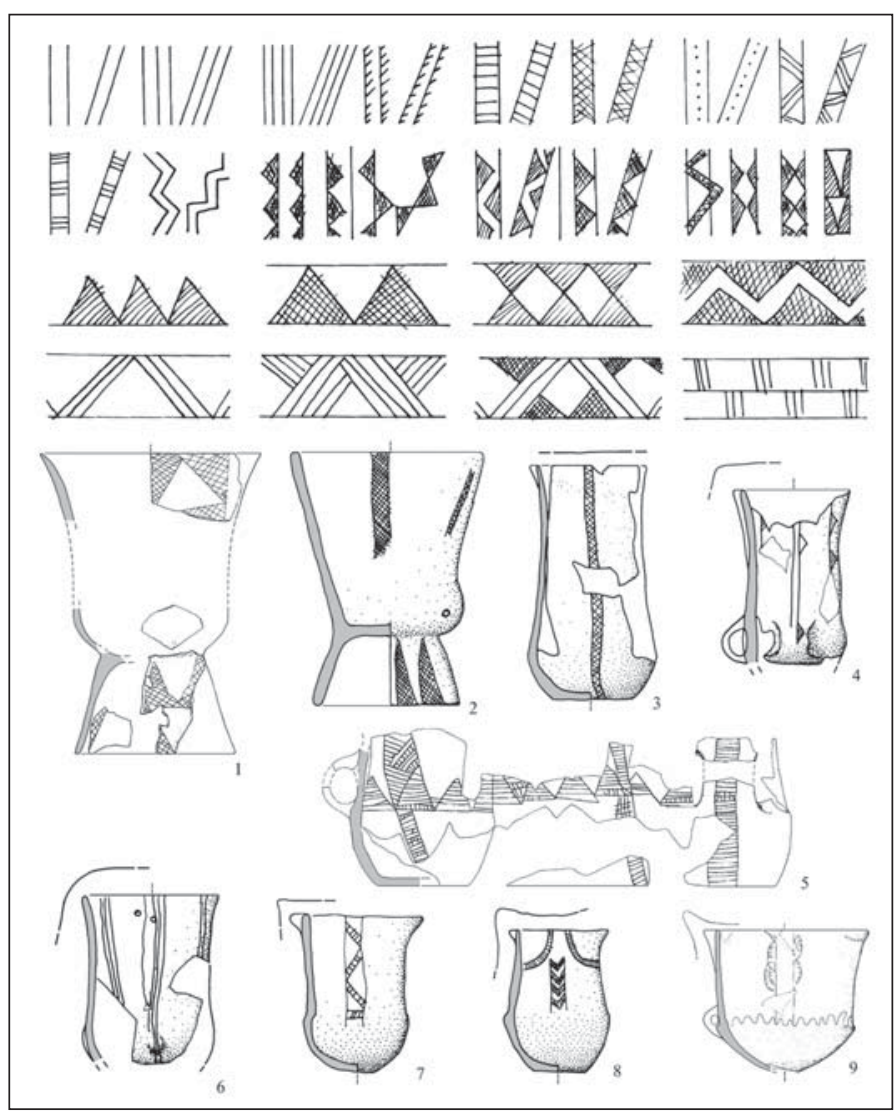

Fig. 1. SMP 1 phase, geometrical scratched style: patterns and forms of pottery. ual and the funerary spheres of the Square Mouth Pottery (SMP) culture. As Christopher Tilley (1996. 215) observes, death, and the ritual practices surrounding it, are far more to do with the living than the dead. In fact, the latter plays an important role in both reflecting and shaping social values and reestablishing social ties of living. By making death into a social occasion, human groups elaborate its social significance, connecting it in various ways to maintaining the social order and cohesion, the cycle of production and distribution of food and wealth, and the renewal or regeneration of life, linked to the fertility of living beings, among which animals have a significant position.

\section{The circle and the square: the SMP culture}

At the beginning of the $5^{\text {th }}$ millennium calBC, the different traditions of the Early Neolithic Padan groups are replaced by the SMP culture, which occupies the whole of northern Italy. Local roots and cultural inputs from southern Italy, the Balkans and the Danube Basin contribute to the making of a distinctive culture, with a pronounced identity and a high-degree of uniformity, in spite of some regional divisions. The square mouth of the vessels, manifestly not due to any convenience in use, seems to lack a specific purpose, since it is applied to items having different functions. However, it appears for over a millennium within extremely disparate cultural terms, as reflected in different pottery styles. The choice of the square mouth means the choice of a completely conceptual and artificial shape, $\mathbf{1}$ absolutely different from all contemporaneous pottery traditions, which could be seen as a distinguishing trait and the marker of a deeply felt cultural identity (Mazzieri and Bernabò Brea, forthcoming).

\footnotetext{
1 In regard to square or rectangular houses, Jacques Cauvin underlines how the creation of geometrical structures is strictly connected to the creation of abstract shapes strongly linked to the Neolithic outlook: Ce langage des formes géométriques recoupe sans doute en partie certaines symétries observables dans la nature (astres, fleurs, coquillages, constellations), mais nous le trouvons d'emblée / un haut niveau d'abstraction, indépendamment de toute intention figurative... Le rectangle, dont la nature quotidiennement observée ne nous offre guere d'exemple, nécessite davantage l'initiative humaine pour exister: la pierre n'est cubique ou rectangulaire que si on la façonne. Le carré et le rectangle connotent donc le manifesté, le concret, le réalisé... L'habitat au carré témoigne d'une attitude mentale différente, ou le progres du savoir technique rencontre l'initiative qui l'utilise, laquelle imposehn besoin de base, celui de s'abriter, une forme entierement nouvelle, artificielle, préconçue (Cauvin 1997.177-179).
} 
SMP culture is divided into three main phases, marked by variations in pottery decorations. The first is characterised by the presence of fine-ware pottery decorated with geometrical scratched patterns (Fig. 1). This phase can be dated between 4900 and 4500 calBC. The second, with incised spiral pattern decorated pottery (Fig. 2), appears between 4500 and 4300 calBC. The appearance of the first Chassey groups around the 4300 calBC marks the end of the development of the SMP in north-western Italy, whereas it continues in the north-eastern regions with clear transalpine influences. The third phase of SMP culture, characterized by the presence of impressed and incised decoration, continues until 4000 calBC. As of now, no funeral evidence is ascribed to this phase, therefore it is not considered here.

Unfortunately, there is no well defined absolute chronology for the numerous SMP graves in northern Italy, since the ${ }^{14} \mathrm{C}$ dates are few. In fact, we only have four absolute dates obtained from grave 2 of Bancole in Lombardy (Starnini and Voytek 2005. 397) and from graves 1, 2 e 4 of La Vela di Trento (Degasperi et al. 2006.157). Two pertain to the first SMP phase, while the other two can be ascribed to the second phase. Because of a large margin of error, two other dates, from burials VI and VII of the Arene Candide Cave, cannot be considered (Maggi 1997.Tab.2). The recent discoveries in Emilia have given the opportunity to improve our knowledge of the funerary practices of SMP people, as well as to date some SMP burials from three important sites: Le Mose, Vicofertile and Parma-via Guidorossi (Tab. 1 and Fig. 3).
The exchange network is wide, starting from the debut of the SMP culture, and includes several raw materials such as flint from the first Alpine foothills (Monti Lessini), green stones from western Alps, vitreous quartz from Alpine regions, obsidians from Sardinia, Lipari and in a smaller quantity, from Pon$\mathrm{za}$, and objects such as fine buff (figulina) pottery from southern regions. The widespread taste for spiral patterns in the pottery decoration of the second phase is probably due to Balkan influences, while the funerary rituals show a resemblance to those of central European Danubian cultures.

Systematic work regarding the everyday subsistence of SMP populations has been carried out only for a few settlements. The faunal assemblage of the Arene Candide Cave in Liguria is surely the biggest sample and the best studied (Rowley-Conwy 1997). In many SMP communities, meat is provided mostly by cattle, sheep/goats and, in smaller quantity, pigs, while wild animals are sparsely represented. On the whole, domesticated animals are prominent, such as in the Arene Candide Cave, Casalnoceto in Piemonte ( $\mathrm{Ai}$ mar 1998), Casatico di Marcaria in Lombardy (Barker 1983), La Vela in Trentino (Bazzanella 2002), and also in some of the recently excavated sites in Emilia (De Grossi Mazzorin, forthcoming). The wild animal presence in the faunal assemblage is predominant in a few sites only. This is due to the peculiar location of the settlements, such as at Mezzocorona Borgonuovo in Trentino (Bazzanella et al. 2002) or Fimon Molino Casarotto in Veneto (Barfield 1971), or in particular ritual contexts like La Razza di Campegine (Cazzella et al. 1976; Bernabò

\begin{tabular}{|lcccccc|}
\hline Site & Feature & $\begin{array}{c}\text { Laboratory } \\
\text { number }\end{array}$ & $\begin{array}{c}\text { Sample } \\
\text { material }\end{array}$ & $\begin{array}{c}\text { Radiocarbon } \\
\text { age (BP) }\end{array}$ & $\begin{array}{c}\text { Calibrated date (BC) } \\
\text { 94.5\% probability }\end{array}$ & $\begin{array}{c}\text { Calibrated date (BC) } \\
\text { 99.7\% probability }\end{array}$ \\
\hline Vicofertile & grave 3 & LTL-4569A & human bone & $5357 \pm 50$ & $4328-4051$ & $4346-3992$ \\
\hline Le Mose & grave 36 & LTL-1530A & human bone & $5419 \pm 55$ & $4360-4057$ & $4448-4044$ \\
\hline Le Mose & grave 12 & LTL-1349A & human bone & $5447 \pm 60$ & $4449-4071$ & $4458-4048$ \\
\hline $\begin{array}{l}\text { Parma - } \\
\text { via Guidorossi }\end{array}$ & grave 29 & LTL-4570A & human bone & $5488 \pm 45$ & $4449-4257$ & $4464-4173$ \\
\hline $\begin{array}{l}\text { Parma - } \\
\text { via Guidorossi }\end{array}$ & grave 28 & LTL-4573A & human bone & $5520 \pm 45$ & $4457-4267$ & $4494-4245$ \\
\hline Le Mose & grave 5 & LTL-1348A & human bone & $5543 \pm 55$ & $4494-4268$ & $4544-4244$ \\
\hline Le Mose & grave 37 & LTL-1531A & human bone & $5594 \pm 50$ & $4521-4345$ & $4603-4327$ \\
\hline Le Mose & grave 1 & LTL-1528A & human bone & $5658 \pm 75$ & $4684-4355$ & $4778-4327$ \\
\hline Vicofertile & grave 2 & LTL-4571A & human bone & $5740 \pm 45$ & $4707-4489$ & $4770-4449$ \\
\hline Le Mose & grave 24 & LTL-1351A & human bone & $5766 \pm 50$ & $4725-4491$ & $4788-4457$ \\
\hline Le Mose & grave 28 & LTL-1353A & human bone & $5900 \pm 45$ & $4906-4685$ & $4949-4590$ \\
\hline
\end{tabular}

Tab. 1. New chronometric evidence from SMP burials of Emilia. Dates were performed by Accelerator Mass Spectrometry (AMS) by Centro di Datazione e Diagnostica (CEDAD) of Lecce University (Italy). Calibration: OxCal v. 4.1.5 (Bronk Ramsey 2010); Atmospheric curve (Reimer et al. 2009). 
Brea and Mazzieri, forthcoming).

The pollen cores available for some of the Emilia sites show in the surroundings of the settlements a tree cover of deciduous mixed oak woodland, with open areas used for legumes and cereal cultivation (Marchesini et al., forthcoming). Meanwhile, micromorphological analyses conducted on some of the Po Plain settlements reveal climatic stability during the $5^{\text {th }}$ millennium calBC, which permitted the development of soils rich in nutrients and stable in structure. There is evidence of slash and burn clearance of woodland, but its impact is not as great as in later periods such as the Copper Age (Cremaschi, forthcoming). What has been excavated thus far suggests the coexistence in the Po Plain of three different environments: original forest probably far from the sites, more open woodland not so far from the villages, and open cultivated areas immediately around the settlements.

\section{Death and burials: SMP funerary traditions}

Whereas there is almost no evidence of the first Neolithic funerary rituals, many data are available for the SMP culture. In fact, SMP burials are well-known from Liguria, the central Po Plain, western Veneto and Trentino (Bagolini and Grifoni Cremonesi 1994.155-160) with shared features, reflecting a collective and shared identity whilst having at the same time different funerary traditions connected to cultural and environmental peculiarities (Fig. 4). Burials are in simple earth-dug graves, within stone circles or in stone cists (Fig. 5). The deceased is usually oriented $\mathrm{E}-\mathrm{W}$, with the head to the East, and the face looking South. The position of the body in the grave is normally flexed on the left side, rarely in dorsal decubitus, with bent legs, while other positions are occasionally attested. In every region, differences regarding the grave, and the position and
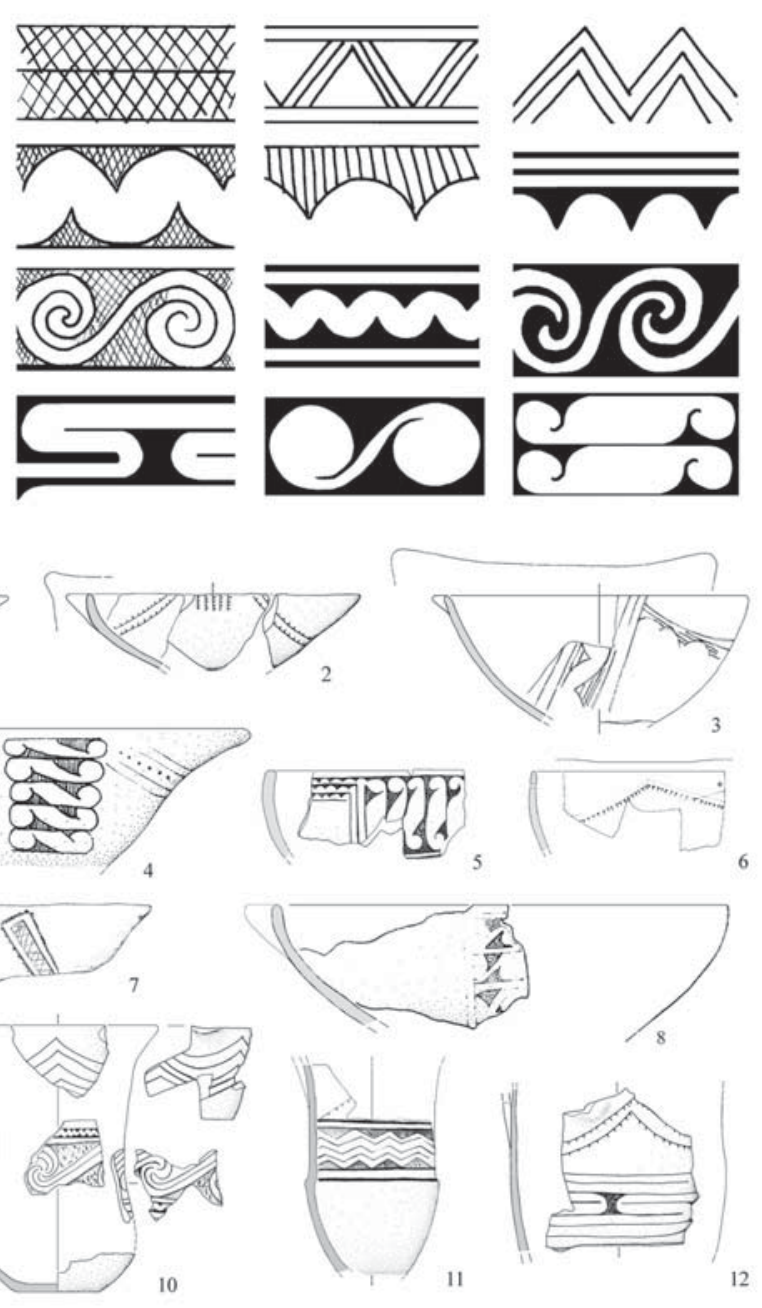

10

12

Fig. 2. SMP 2 phase, incised meander-spiral style: patterns and forms of treatment of the body seem to be in accordance with complex rules connected to gender or the status of the deceased.

\section{Liguria}

There is a good deal of information on the SMP mortuary practices in the Liguria caves finds, especially from Arene Candide (over 40 inhumations), La Pollera ( 47 burials) and Grotta dei Pipistrelli (10 burials). The first discoveries can be dated to the $19^{\text {th }}$ century (Issel 1908.376-393) and to the first half of the 20th century (Bernabò Brea 1946.19; Del Lucchese 1997). In these graves, adults were enclosed in stone cists, while the infants' graves were usually without protection. The bodies were in flexed positions, with most of the heads oriented to N or N-E. Some skeletons were set with ochre, which was frequently contained in a vessel. In terms of gravegoods, the richest data come from the burials excavated during the $19^{\text {th }}$ century: at Arene Candide and La Pollera caves, some burials were equipped with 
green stone axes, a pot, bone pins found near the breast, a red-deer antler, a Triton shell, shell and animal teeth ornaments. In some caves, skeleton manipulations are known: an inhumation from which the skull has been removed at La Pollera, and the deposition of skulls within the cave of Arma del Sanguineto (Pessina and Tinè 2008.298).

\section{Western Veneto and Trentino}

Some groups of tombs or isolated burials have been found along the Adige Valley (Barfield 1970), while small necropolises are attested in the southern expanse of the valley in Veneto at Progno di Fumane and Quinzano Veronese (Salzani 1981; Pedrotti 1996). The most important graveyard is La Vela, in the nearby of Trento, which numbers at least fourteen burials (Bagolini 1990; Pedrotti 2001). These are displaced within stone circles or stone cists (Fig. 6 ); the two different kinds of grave are located in separated areas of the graveyard. The bodies are buried in a crouched position on the left side and oriented SE-NW or SSE-NNW. Most of the graves are arranged in pairs; only a child burial (grave 7) is located in isolation. Some remains belonging to an adult male have been found in grave 4 and could represent a secondary burial. Scattered human bones were found in graves 1 and 6 . The occurrence of funerary rituals is attested by the presence of some hearths near the graves. Nine of the fourteen burials excavated are equipped with grave-goods: males are provided with flint objects (blades, arrow-heads), polished stone tools (axes and chisels) and bone pins; females and children with miniature vessels, a Serra d'Alto small flask, bone tools and grind-stones. Pe-

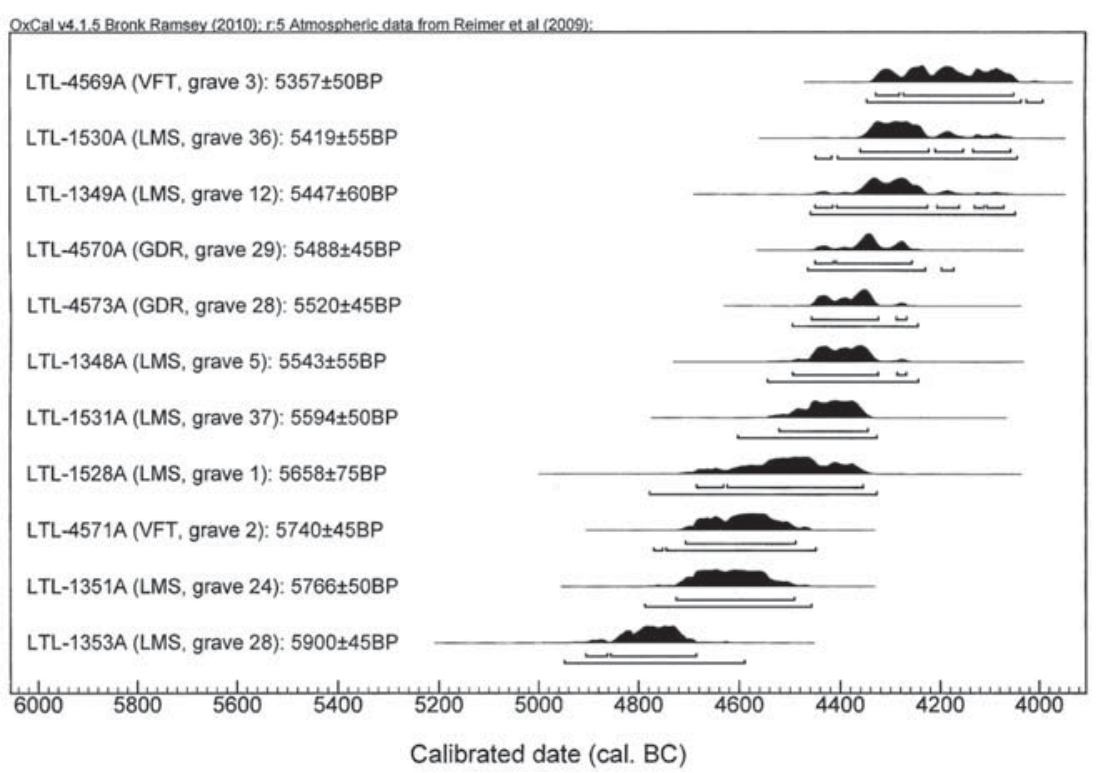

Fig. 3. Calibrated dates from SMP burials of Emilia. Sites: LMS = Le Mose; VFT $=$ Vicofertile $;$ GDR = Parma - via Guidorossi . culiar to this graveyard is the occurrence of personal ornaments made of Spondylus shells. Some of the equipment is particularly rich, as in grave 1 , belonging to an adult male endowed with a chisel, an axe, a flint blade and nine arrow-heads; or grave 3, belonging to a child wearing a bracelet and necklace of Spondylus beads, and equipped with a bone pin and three miniature vessels, one of them containing cinnabar.

\section{Emilia}

Central-western Emilia, which comprises the regions of Piacenza, Parma and Reggio Emilia, offers a good case-study for SMP mortuary practices (Bernabò Brea et al. 2006b; 2007; forthcoming $a$ and b). In this area, some two hundred and thirty burials have been brought to light at seventeen sites (Fig. 7). Single inhumations have been found in some sites, while others show a higher density of burials, sometimes in the shape of small graveyards holding up to fifty-five graves. Some burial groups are also attested (Fig. 8), sometimes arranged in rows, possibly indicating kinship ties between the deceased (Fig. 9).

Both men and women are interred crouched on the left side in simple earth-cut pits. The burials are mostly oriented $\mathrm{E}-\mathrm{W}$, with the face turned to the south (Fig. 10). As the culture develops, the funerary ritual becomes more and more standardized.

There are also burials in huge, irregular-shaped pits and in silos (Fig. 11). Neither scattered human bones within the settlements nor skeleton manipulations have been found on the Po Plain, with the exception of some cases such as skulls and selected bones deposed at the bottom of silos in three settlements (Ponte Ghiara, Le Mose and via Guidorossi). The special care for the skull, as attested by its position at the centre of the pit, reveals a special treatment of the head as defining the identity of the dead. Cremation is rarely attested among SMP funerary practices ( 7 cases, or $3.5 \%$ of burials) - one case at Ponte Ghiara, two at Le Mose and four at Gaione - Cascina Catena. All the cremations determined thus far are of adult fe- 
Fig. 4. Geographical distribution of SMP sites in northern Italy with burials or skeletal human remains: 1 . Arma della Gastea; 2. Tana della Volpe; 3. Arma di Nasino; 4. Arma dell'Aquila; 5. Grotta dei Pipistrelli or Borzini; 6. Grotta del Sanguineto or della Matta; 7. Riparo di Pian del Ciliegio; 8. Arene Candide Cave; 9. La Pollera Cave; 10. Riparo di Alpicella; 11. Grotta di Aisone; 12. Santa Maria; 13. Le Mose; 14. Ponte Ghiara; 15. Castelguelfo; 16. Pontetaro; 17. Collecchio (Tangenziale and Ca' Lunga); 18. Vicofertile; 19.

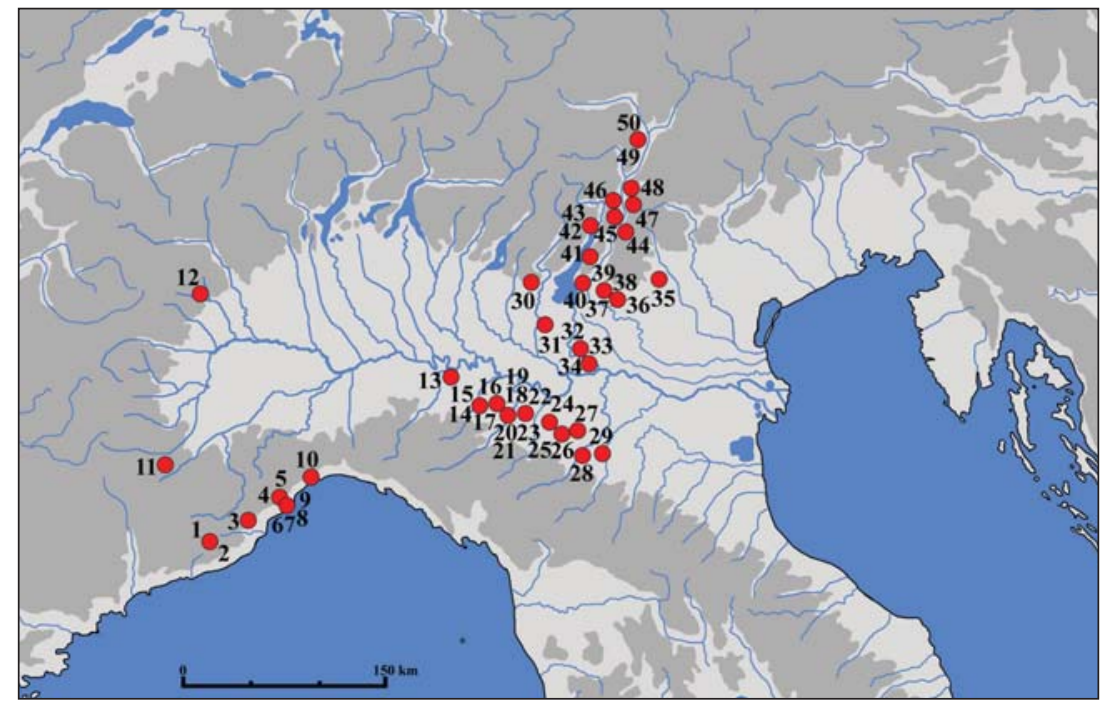
Parma (Benefizio and via Guidorossi): 20. Gaione (Cascina Catena, Cinghio and La Perla); 21. Marano; 22. Sant'Ilario d'Enza - Loghetto and Calerno - Ca' Nuova; 23. La Razza di Campegine; 24. Reggio Emilia - via Rivoluzione d'Ottobre; 25. Chiozza di Scandiano; 26. Albinea and Rivaltella - Ca' Romensini; 27. Formigine, Cantone di Magreta; 28. Pescale, Prignano sul Secchia; 29. Spilamberto, Cava Camer - La Dottora; 30. Nave - Località Mulino; 31. Casalmoro; 32. Bancole - Porto Mantovano; 33. San Giorgio di Mantova; 34. Bagnolo San Vito; 35. Fimon - Molino Casarotto; 36. Quinzano Veronese; 37. Campagnole di Negarine, San Pietro in Cariano; 38. Santa Maria di Negrar; 39. Progno di Fumane; 40. Rocca Rivoli; 41. Malcesine - Campo Manesch; 42. Riva del Garda, Cava di Monte Brione; 43. Romarzolo - Chiarano; 44. Rovereto, La Sticcotta; 45. Pederzano - Pal Alto; 46. La Vela di Trento; 47. Martignano (Maso Mersi and Montevaccino); 48. Meano - Alle Pergole; 49. Dambel; 50. Appiano/Eppan.

males and seem to represent a special ritual practice. In some necropolises (Vicofertile and Gaione Cinghio) among the burials, some pits with no bodies (cenotaphs) have been found. No grave-goods or objects have been found in these pits. Cenotaphs are common in the $5^{\text {th }}$ millennium calBC in the Balkans, but are also attested in the Danube Basin and central Europe (Bailey 2000).

Burials dated to the first SMP phase generally have no grave-goods, whereas between $30 \%$ to $60 \%$ of second phase burials, including those of children, are equipped with objects. The grave-goods indicate a very marked gender distinction. Male burials are provided with flint artefacts (blades and arrowheads) and polished stone tools (axes and chisels) and rare antler artefacts (Fig. 12.1-6). Among gravegoods, green-stone axes are decidedly the most characteristic element, even though arrow-heads are also strongly represented. Female grave-goods include SMP pots, small flasks imitating the peninsular Serra d'Alto culture pottery, bone spatulas and awls and personal ornaments (Fig. 12.7-9). Pots found inside the burials are usually undecorated, unlike pottery from the settlements, which is usually richly decorated. In both cases, the separation between everyday objects and items intended for the deceased seems clear. ${ }^{2}$ These funerary pots may simply have stood for a symbolic meal partaken by the dead.

So far, only two female burials figurines are known, from the necropolis of Vicofertile (grave 3) and from via Guidorossi (grave 55). The first accompanied an adult woman (Fig. 13); it is $19 \mathrm{~cm}$ high and the depiction is particularly accurate. It reproduces some SMP figurine features - the seated pose, the hip size, arms folded under the breasts, the prominent bird bill nose, the realistic hairstyle and the absence of a mouth (Bernabò Brea 2006; Bernabò Brea and Cultraro, forthcoming). The last two characteristics are particularly interesting, because there is a contrast between the precision in the depiction of the hair and the symbolic absence of the mouth. The latter in particular seems to stress the inability to speak, as in the world of the dead. Furthermore, the body rigidity and the flat breasts probably also refer to this sphere. The bird bill nose, instead, shows a syncretism between the human and animal worlds, and in particular, between the woman and birds, which are often related to each other in many

2 In Trentino and in Mantua territory the presence of miniature vessels in graves is quite common, in contrast to settlements, where they are extremely rare. 


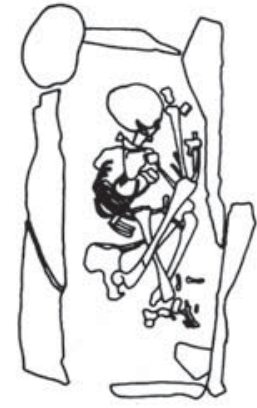

1

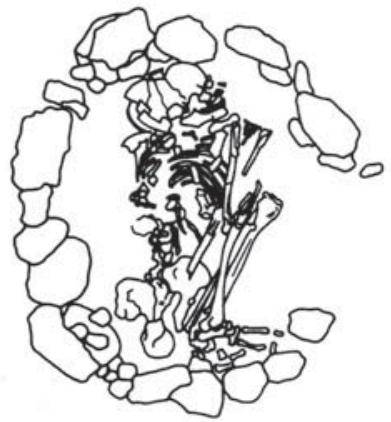

2

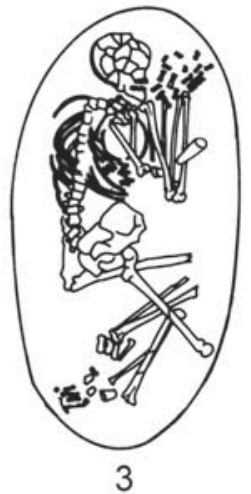

3 placed in a pit with the explicit aim of binding it to that place, as it was believed to be a guardian (Bernabò Brea and Mazzieri, forthcoming). So far, depositions of other domestic animals in SMP settlements are not attested.

Wild animal depositions within features or silos in SMP settlements are rather widespread. One of the most intestone circle; 3. Simply earth-dug grave (after Bagolini 1992). resting cases is the huge irregular pit excavated in 1974 at Razza di Campegine, because it contained several well preserved faunal remains. A large red deer antler and two female wild boar skulls were deposited at the base of two silos, a humerus of a big wolf and other remains of auroch and badger were scattered inside the feature (Cazzella et al. 1976.113). The wild boar were large, and consistent with subspecies now living exclusively in eastern Europe (Sus Scrofa Attila). At Parma

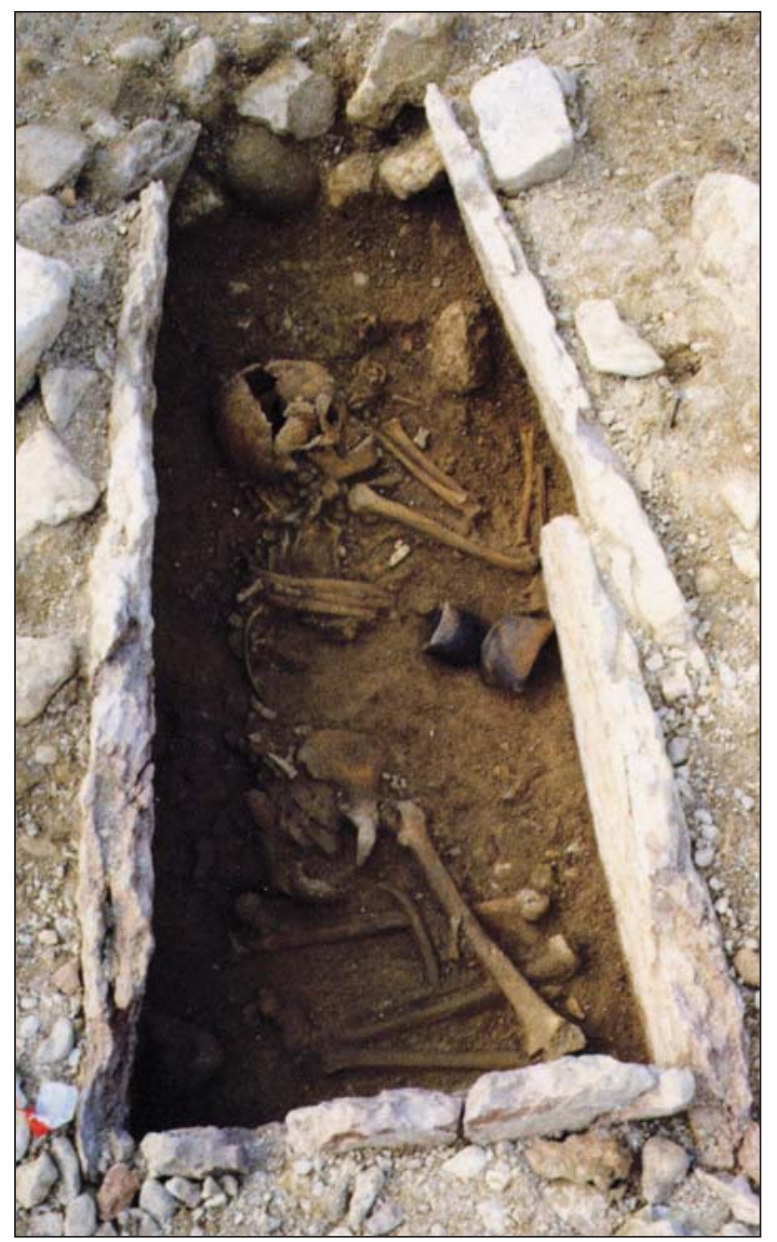

Fig. 6. Stone cist grave of an adult female from La Vela di Trento (grave IV) (after Mottes 2007). 
Fig. 7. Geographical distribution of SMP burial sites in the Emilia region: 1 . Le Mose; 2. Ponte Ghiara; 3. Castelguelfo; 4. Pontetaro; 5. Collecchio (Tangenziale and Ca' Lunga); 6. Vicofertile; 7. Parma (Benefizio and via Guidorossi; 8. Gaione (Cascina Catena, Cinghio and La Perla); 9. Marano; 10. Sant'llario d'Enza - Loghetto and Calerno Ca' Nuova; 11. La Razza di Campegine; 12. Reggio Emilia - via Rivoluzione d'Ottobre; 13. Chiozza di Scandiano; 14. Albinea and Rivaltella - Ca' Romensini; 15. Formigine, Cantone di Magreta; 16. Pescale, Prignano sul Secchia; 17 Spilamberto, Cava Camer - La Dottora.

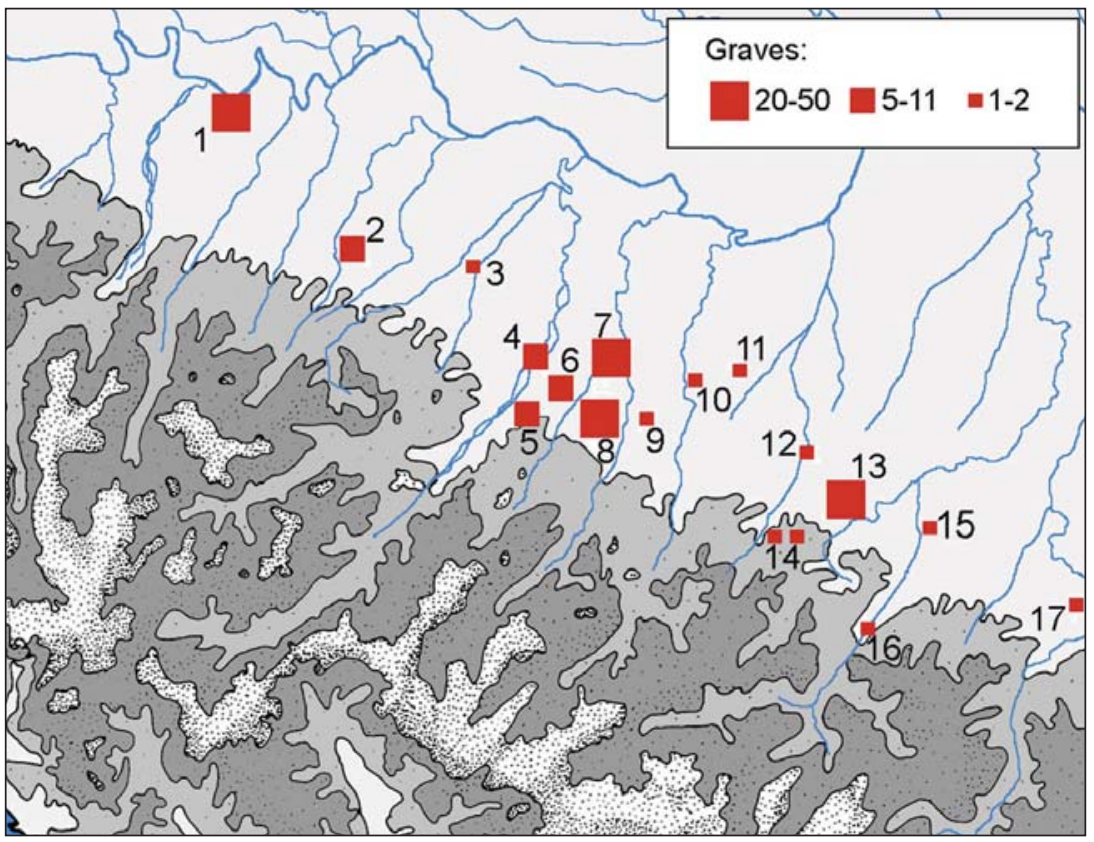

- Benefizio settlement, numerous auroch remains were at the top of a silo containing a vase cut in two and lying on a cobbled hearth (Mazzieri and Grignano, forthcoming). From via Guidorossi, we have two unusual depositions: in the first case, two snakes twisted together as in copulation were found at the base of a silo; in the second case, two medium-size birds whose species has not yet been determined were buried complete in two different pits (Bernabò Brea and Mazzieri, forthcoming). Such findings suggest some ritual deposition. In fact, snakes do not usually copulate underground, and when they are in their nest, they maintain a coiled position, not a twisted one. Snakes are linked with the chthonian and water worlds; therefore, this discovery could testify to some ritual action connected with these spheres. The snake has no comparison in the Italian Neolithic iconography and there are no data on its occurrence in funeral or daily contexts. As for the birds, we have other evidence from Pontetaro in Emilia, where a rough terracotta bird head with an epiphysis imprint at its base was discovered (Fig. $15)$.

Some of the Emilia evidence can probably be ascribed to sacrifices or funerary feasts. Over and among the heaps of stones covering two male burials at via Guidorossi, some as yet undetermined faunal remains were found. Thus far, the only certain burial context testifying to a funeral feast relates to a buried woman suffering from tuberculosis and osteomyelitis which was found in the via Guidorossi graveyard (grave 24). The offerings consisted of broken fine-ware pots, hazelnuts, cattle, pig, sheep/goat and pike remains.

\section{Personal ornaments and SMP Neolithic groups: an overview}

SMP personal ornaments, both from settlements and burials, were made of various materials in a wide range of forms. This wide range can be attributed to the vast territorial extension and the longevity of SMP culture. Differences are particularly notable between Liguria, the Po Plain (western Emilia and Man-

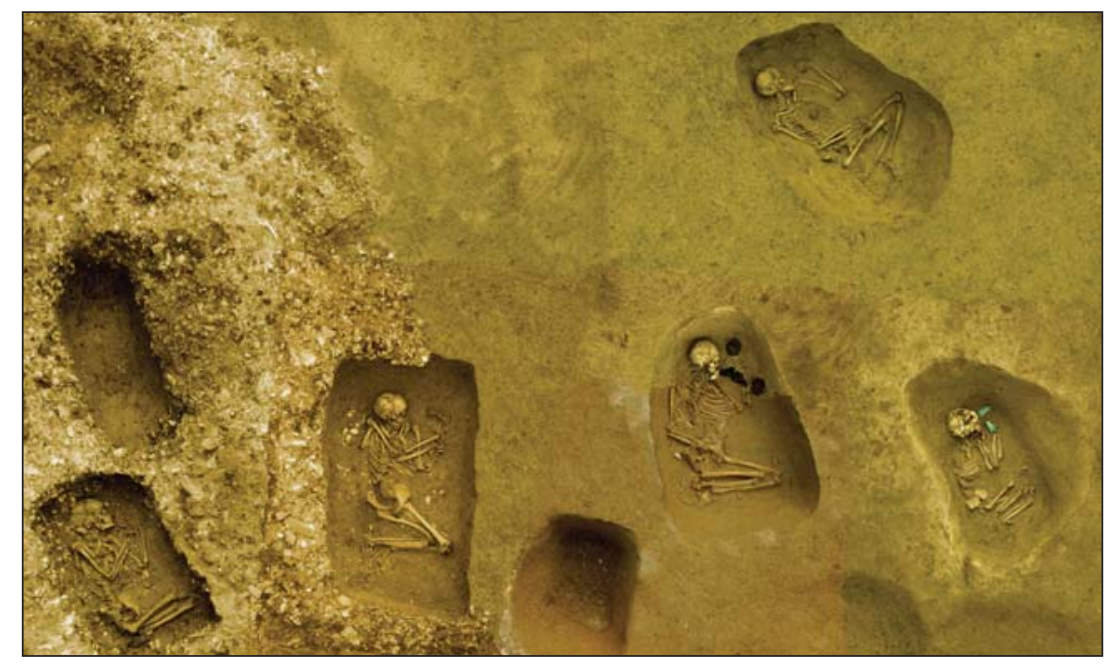

Fig. 8. Vicofertile burial site. 


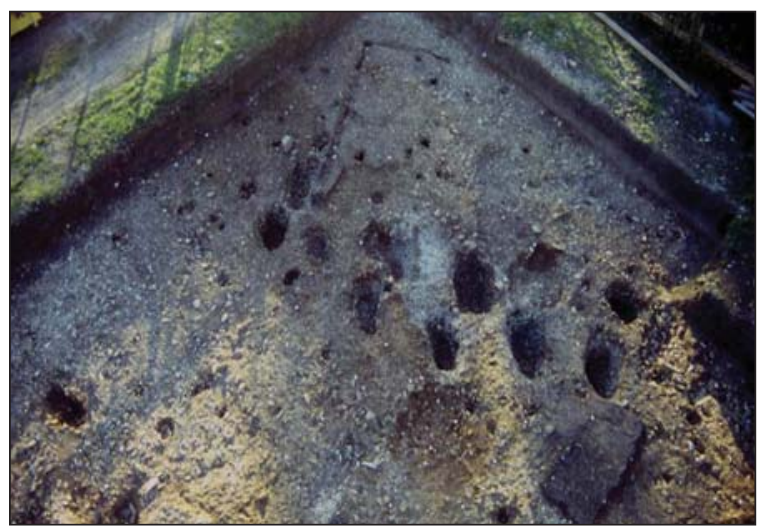

Fig. 9. Gaione - Cinghio: graves arranged in a double row.

tua territory) and Trentino. Regarding grave goods, personal ornaments accompanied female burials almost exclusively, adult or child, except in Liguria.

\section{Shell and tooth: personal ornaments from Li- guria}

Data regarding ornaments in Liguria come almost exclusively from Arene Candide and La Pollera caves. The use of shells (Columbella rustica, Cardium sp. and Glycymeris sp.), perforated bones and teeth is well attested, while elaborated ornaments such as discoid and cylindrical beads and bracelets are very rare. The data from the Liguria settlements also point to the importance of perforated animal teeth in the settlements, as shown at the Arene Candide Cave. The relevance of these objects in the SMP levels and their absence in the other horizons during the Neolithic is clear (Fig. 16). The most common teeth are the canines of canids (dog, fox and wolf); red-deer canines are rarer, as are those of felines (wild cat and lynx), mustelids (badger and polecat) and bear. Boar tusks, simply pierced or employed to make peculiar pendants, are also registered. The perforated bones include lower jaws, phalanges, metacarpus and metatarsus of wild animals. The only perforated bone of a domestic animal is a goat metapodial.

Interesting data come from three graves excavated in the late $19^{\text {th }}$ century: at La Pollera, a female burial was endowed with six perforated teeth of an undetermined canid associated with a perforated lynx lower jaw; one adult burial at the Arene Candide Cave had a perforated wild boar tusk on the thorax and a red deer antler as equipment, while in another grave, three wolf canines were found around the neck of an adult (Issel 1908.337, 409; Delfino 1981. 105). From the same cave comes a necklace (Fig. 17) consisting of fox, wild cat and dog perforated teeth,

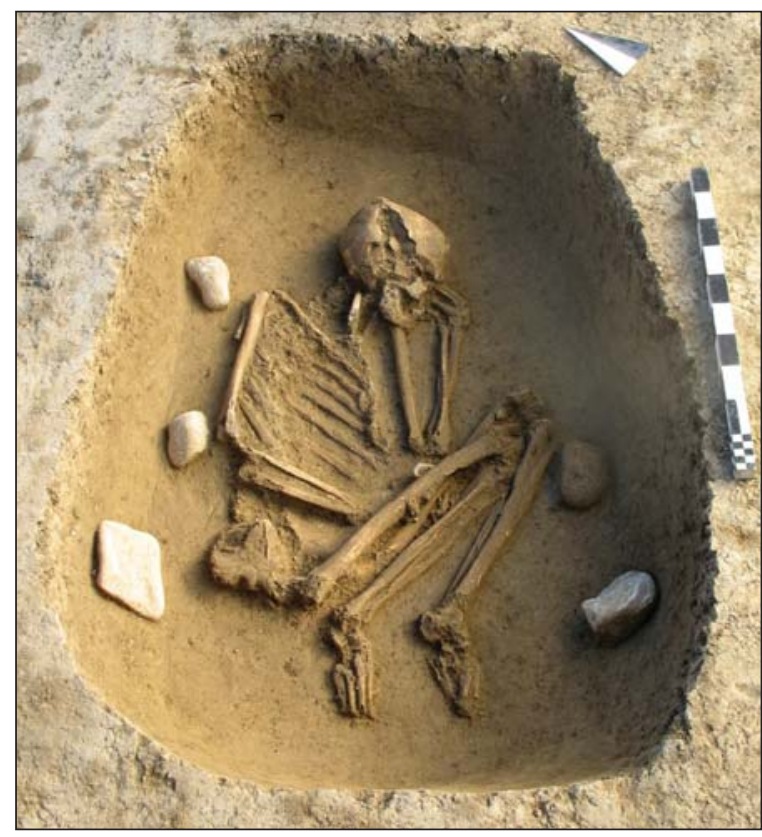

Fig. 10. Parma - via Guidorossi (grave 30): earthdug grave of an adult male.

as well as bird bones and arc-shaped shell pendants, probably imitating carnivores' large canines or claws (Bernabò Brea 1956. 110-111, Fig. XXXIII; Micheli 2004.Fig. 13). The use of perforated bone and teeth is a new phenomenon compared to northern Italy first Neolithic and therefore particularly interesting, since it reveals the preponderance of wild over domestic animals. The dog is the only domestic animal which is strongly represented.

Exotic materials in central Alps: the case of Trentino

Data on personal ornaments in Adige Valley come from the necropolis of La Vela (Pedrotti 2001), from the rock-shelters of Moletta Patone di Arco (Bagolini et al. 1984) and of Mezzocorona Borgonuovo

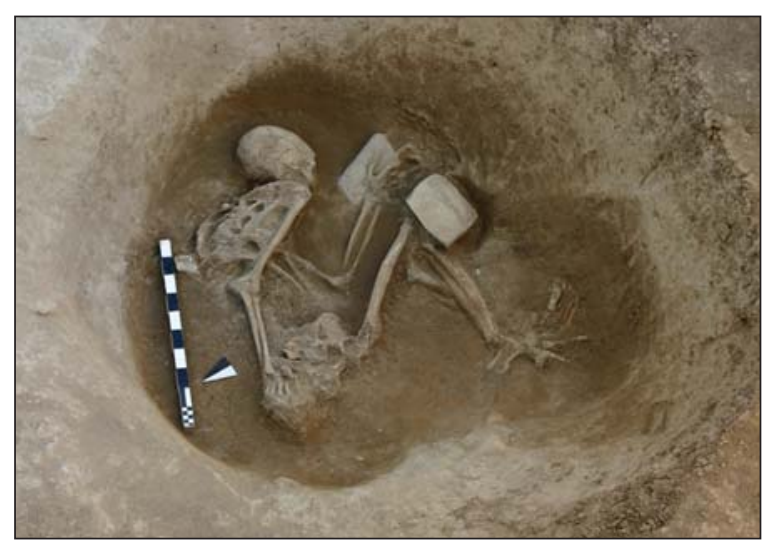

Fig. 11. Parma - via Guidorossi (grave 16): silo burial of an adult male. 


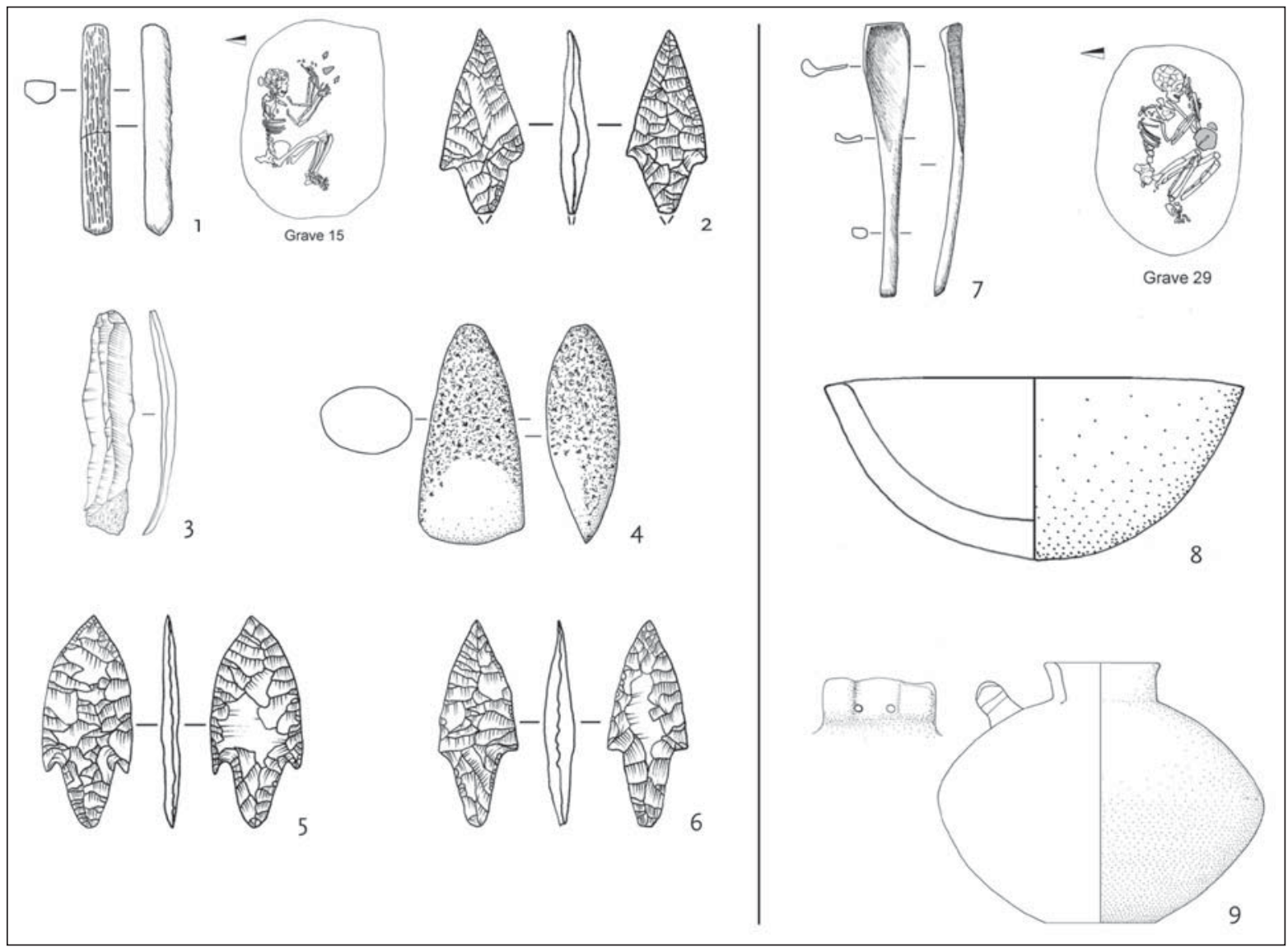

Fig. 12. Parma - via Guidorossi: 1-6. Adult male grave-goods (grave 15); 7-9. Adult female grave-goods (grave 29).

(Bazzanella et al. 2002) and from the settlement of via Brione at Riva del Garda (Micheli, forthcoming). The use of exotic raw materials in the manufacture of personal ornaments, such as beads in steatite from the Apennines and pierced sea shells (Columbella rustica) and Spondylus (Bagolini 1990; Micheli, forthcoming), is well attested and widespread among the SMP groups of Trentino.

The use of perforated teeth, including red-deer canines and boar tusks, or drilled pebbles is more rare, however. The special feature of personal ornaments in Trentino is the presence of Spondylus beads, as attested at La Vela necropolis (Bagolini 1990; Pedrotti 2001), Moletta Patone rock-shelter (Bagolini et al. 1984) and Riva del Garda settlement (Miche$l i$, forthcoming). 3 The beads are cylindrical, sometimes long and thick, or smaller and shorter, or discoidal. Their frequency can be connected to the diffusion of Danubian elements (Bagolini 1990; Borrello, Micheli 2004). It is worth mentioning that in the central Alps area, some fossil Spondylus depo- sits are known which could have been exploited by Neolithic populations (Micheli, forthcoming).

\section{Types and raw materials of central Po Plain personal ornaments}

In the central Po Plain during both the first and second phase of SMP, steatite pendants and beads, Dentalium shells, fossil Serpulidae and perforated teeth are the most frequent personal ornaments. Many data concerning such objects come from recently excavated settlements and graveyards in Emilia. The SMP Emilia groups are characterized by the production of personal ornaments fashioned from black steatite collected from the numerous deposits sited in the central-western Emilia Apennines (Bernabò Brea et al. 2006a). Perforated animal teeth are important elements in Emilia SMP customs: mainly dog teeth - the only domestic animal represented - fox, and very seldom bear. Three of the seven burials provided with ornaments at via Guidorossi had perforated animal tooth pendants. These

3 These beads come from a peripheral area of the settlement and, in view of their similarity to the beads from La Vela graves, the hypothesis that they could be grave-goods of disturbed burials cannot be refused. 


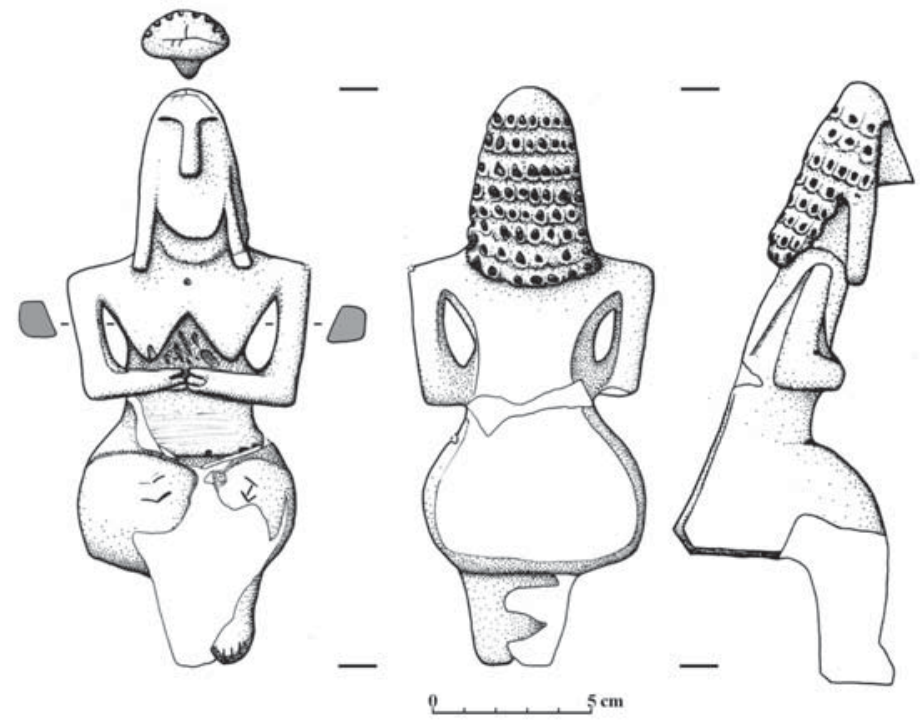

Fig. 13. Vicofertile (grave 3): female terracotta figurine from an adult female burial.

ornaments have been found around the neck of women: two fox canines from grave 27 (Fig. 18), a dog canine from grave 19 and a necklace consisting of one molar, three premolars, two canines and two incisors from a very old $\operatorname{dog} 4$ from grave 37 (Fig. 19). From Chiozza graveyard comes a bear canine (Bagolini, Barfield 1971.Fig. 23.5).

The occurrence of a necklace formed by four pike vertebrae, belonging to a small specimen, inside the grave of a female child at Le Mose graveyard is exceptional in the Neolithic. The pike is a predator of the Po River and sometimes reaches considerable dimensions; its presence in the Padan fluvial system is seasonal, being related to its prey. A large antler hook found in a male burial from the same gra-

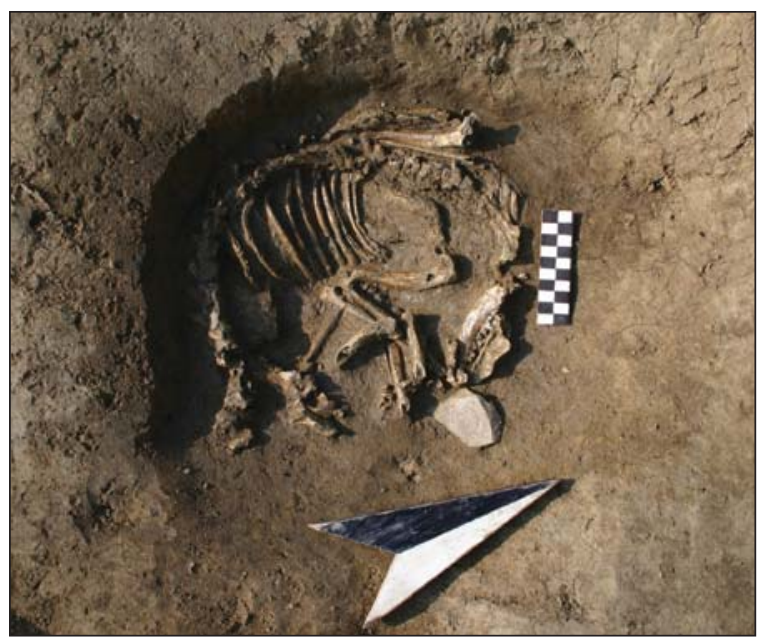

veyard could be linked to pike fishing.

Regarding the use of perforated bones as items of adornment, two pendants made from hare metatarsus with a transversal hole were found at Fimon-Molino Casarotto (Bagolini et al. 1973.204, Fig. 33.6-7) that are comparable to similar perforated bones from the $19^{\text {th }}$ century excavations at the Arene Candide Cave (Bernabò Brea 1946.Fig. LXIII).

The employment of perforated human teeth as pendants is very rare in prehistory; nevertheless, such objects are attested at two SMP sites. An abraded perforated human canine (Fig. 20) was worn by a 30-40-year-old woman at via Guidorossi (grave 6) (Mazzieri, forthcoming), while five drilled human teeth pendants have been brought to light in the settlement of Fimon-Molino Casarotto (Bagolini et al. 1973.Fig. 331.5). Their use is not only decorative, since wearing a human tooth pendant implies strong symbolic values and a direct link with the person to whom the tooth belonged, and could have had diverse purposes: as amulets against magic and illness, trophies or signs of affection. A human premolar imitation in black steatite comes from surveys at the Gaione - S. Ruffino settlement.

Unlike Liguria and Trentino, red deer canines have not been attested so far in the Emilia territory. Ne-

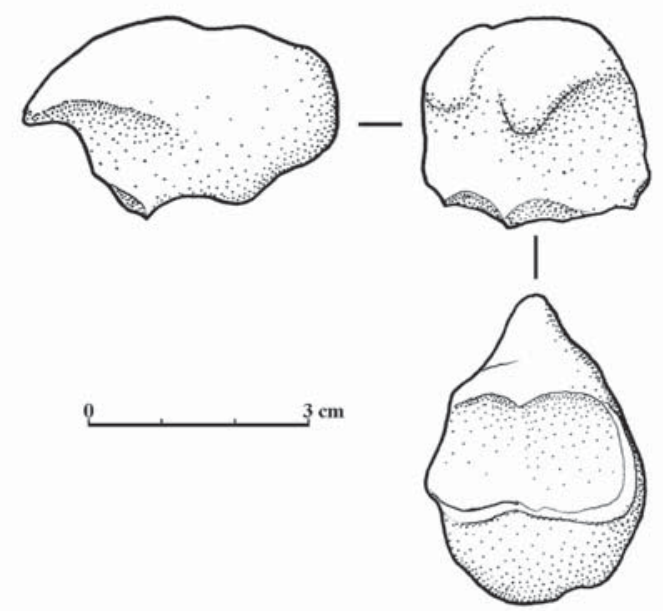

Fig. 14. Parma - via Guidorossi: dog burial. Fig. 15. Pontetaro settlement: rough terracotta bird head with an epiphysis imprint at its base.

4 Determination by Alice Choyke. 
vertheless, we know some imitations in bone in grave 53 of via Guidorossi (Fig. 21) and steatite from the Gaione - Cascina Catena and Pontetaro (Fig. 22) settlements, suggesting the symbolic importance of red deer canines for the SMP people of Emilia as well. Concerning red deer, it is noteworthy that a steatite object probably reproducing a leg of a zoomorphic figurine was found at the Gaione - San Ruffino settlement.

\section{Animals and their implica- tions in ritual}

Regarding animal ritual depositions, only the finds in the Po Plain allow any deductions. As far as grave-goods and ritual practices are concerned, domesticated species, except for dogs, are scarcely represented. Bone spatulas and awls obtained from sheep/ goat metapodials are included almost exclusively among the female grave-goods of some graveyards (Le Mose, Collecchio, via Guidorossi and Chiozza). Precisely the same types of artefact have been found repeatedly in settlements.

Among the domesticated species documented, dogs play the main role, as they were interred inside, or nearby, burials or in huge irregular-shaped pits, cremated with a human being, and their canines have been used for personal ornaments (Tab. 2).

A red deer antler and three antler artefacts are placed in burials as offerings or as grave-goods. At Pontetaro, an antler (Fig. 23) was placed under the head of an adult male (Mazzieri and Mutti, forthcoming). Two antler sticks were found inside two richly equipped burials from the via Guidorossi (grave 15) and Le Mose (grave 6) graveyards; they are enigmatic
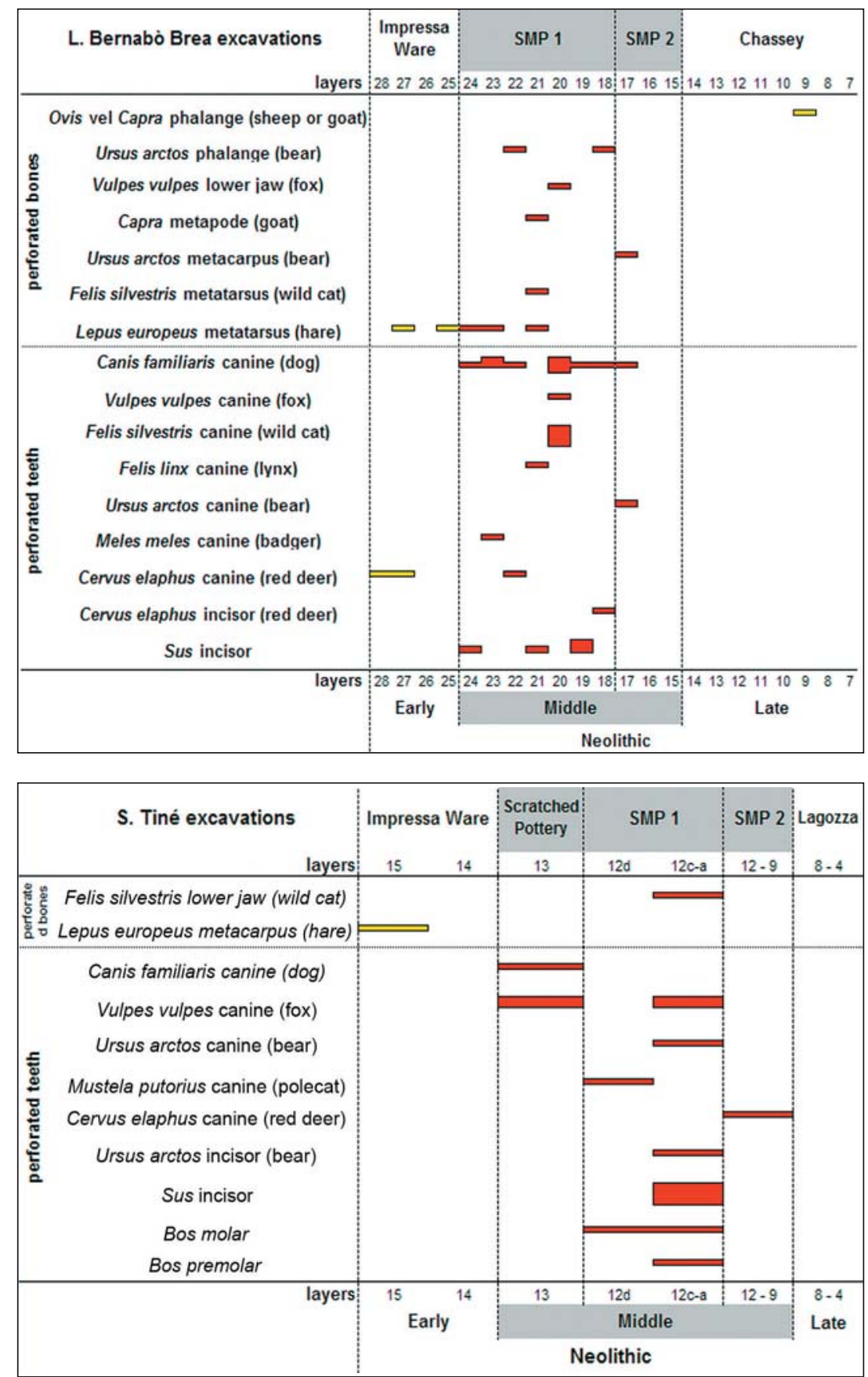

Fig. 16.1 and 2. Frequency of perforated bones and teeth in the Neolithic deposits of the Arene Candide Cave: 1. Luigi Bernabò Brea's excavations (1940-42 and 1948-50); 2. Santo Tiné's excavations (1972-1977).

objects, lacking any apparent function (Figs. 12.1 and 24), and may have a symbolic value similar to that of the antler itself. Among the objects in the funerary equipment of grave 6 there was a large antler hook. Different meanings can be attributed to these finds. In some cases, they can be interpreted as 'hunting trophies', such as the antler, declaring the personal valour of the deceased. They can also be seen as regeneration symbols, because the deer renews its antler every year; and as a virility 


\begin{tabular}{|c|c|c|c|c|c|}
\hline \multirow{2}{*}{ Site } & \multirow{2}{*}{$\begin{array}{l}\text { SMP } \\
\text { Phase }\end{array}$} & \multirow{2}{*}{ Dog remains } & \multirow{2}{*}{ Context } & \multicolumn{2}{|c|}{ Human remains } \\
\hline & & & & From the same grave & Nearby \\
\hline Ponte Ghiara & Early 1 & selected cremated bones & cremation grave & $\mathrm{F}, 20-40$ years (grave 2 ) & - \\
\hline Ponte Ghiara & Early 1 & 2 perforated teeth & layer, settlement & - & - \\
\hline Pontetato & $1-2$ & skeletal without hind legs & dog grave & - & - \\
\hline $\begin{array}{l}\text { Collecchio - } \\
\text { Ca' Lunga }\end{array}$ & Early 2 & scattered bones & inhumation grave & $\mathrm{M}, 18-20$ years (grave 5 ) & - \\
\hline $\begin{array}{l}\text { Collecchio - } \\
\text { Tangenziale }\end{array}$ & Early 2 & 1 perforated tooth & layer, settlement & - & - \\
\hline $\begin{array}{l}\text { Parma - } \\
\text { via Guidorossi }\end{array}$ & 2 & 1 perforated tooth & inhumation grave & $\mathrm{F}, 25-19$ years (grave 19) & - \\
\hline $\begin{array}{l}\text { Parma - } \\
\text { via Guidorossi }\end{array}$ & 2 & 7 perforated teeth & inhumation grave & $\mathrm{F}, 40$ years (grave 37 ) & - \\
\hline $\begin{array}{l}\text { Parma - } \\
\text { via Guidorossi }\end{array}$ & 2 & complete skeletal & dog grave & - & M, c. 25 years (grave 1 ) \\
\hline $\begin{array}{l}\text { Chiozza } \\
\text { di Scandiano }\end{array}$ & 2 & complete skeletal & dog grave & - & M, 30-35 years (grave 2 ) \\
\hline Bagnolo San Vito & 2 & complete skeletal & dog grave & - & $\begin{array}{l}\text { (graves } 4 \text { and } 8: \text { sex and } \\
\text { age not yet published) }\end{array}$ \\
\hline Bagnolo San Vito & 2 & complete skeletal & inhumation grave & $\begin{array}{c}\text { (sex and age } \\
\text { not yet published) }\end{array}$ & - \\
\hline
\end{tabular}

\section{Tab. 2. Dog embodiment in SMP culture: evidence from burials and personal ornaments.}

devices. 5 But the meaning of the antler artefacts is totally different, not being related to exhibition, but instead to a deeply intimate value or a peculiar expertise. The previous form of the antler is unrecognizable in the sticks and hook, because they are the result of the long work of manipulation and mimesis, which required time and skill.

\section{Hunting and its symbolic representations}

The frequent occurrence of flint arrow heads in male burials reflects the relevance of the hunter, and/or perhaps warrior, in the SMP society, and is an expression of the personal status acquired in life through skill and bravery. The hunter can act as a mediator between the domestic world represented by the village and the wilderness symbolized by the animals of the forest. In the SMP world, hunting is not economically relevant, but it takes on great significance as a symbolic activity. The wide range in shape and size of the arrow-heads which equipped SMP male burials (Fig. 25) is surely not due to a chronological discard, since morphologically different arrows have been found within the same grave. This fact could be linked to a type of symbolic abstraction of the hunt. Two hypotheses can be assumed: the first is that a specific correlation between the shape of the arrow-head and kind of game exists, as noticed in many traditional societies (Pétrequin and Pétrequin 1990). The second is that some of the arrow-heads are symbolic and display objects to be shown and used only on particular occasions, as demonstrated by the specimens made of exotic materials such as obsidian and vitreous quartz (Fig. 26) from the via Guidorossi and Pontetaro settlements (Mazzieri, forthcoming; Mazzieri and Mutti, forthcoming).

\section{The symbolic importance of animals}

The data presented so far show the relevance of the wild. The symbolic value of the finds is clear, since they highlight the discrepancy between the subsistence of the SMP groups - which was based primarily on domestic animals - and

Fig. 17. Necklace made with perforated teeth of fox, wild cat and dog, bird bones beads and arc-shaped shell pendants, probably imitating carnivores' large canines or claws (Arene Candide Cave, layer 20 from SMP 1 levels).

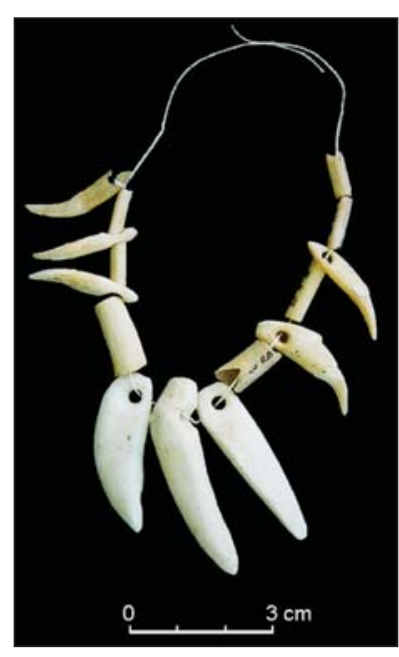

5 The level of testosterone in the adult males' blood determines antler size and competitiveness in reproduction and, consequentially, the position within the social hierarchy. 


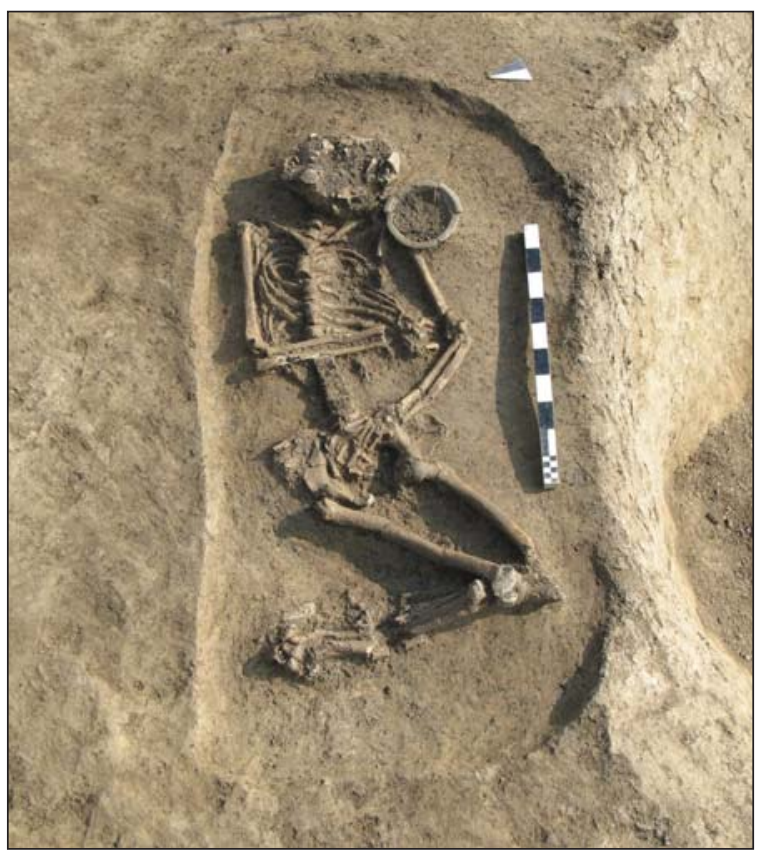

the figurative use of wild animals. The only well attested domestic animal in funerary or ritual contexts, as we have seen, is the dog.

Among personal ornaments, there is a preference for objects referring to the forest and the animals living in it, especially predators. The same preference is attested for the pike among fishes. It is interesting to observe the inclination for animal species with a clear/epiphanic seasonal nature, such as the red deer which sheds its antlers, the hibernating bear, or the sloughing snake etc. Such choices are surely not fortuitous, and may express the regenerative power associated with the undomesticated savage world. It is worth remarking that necklaces that included animal teeth were worn by women in the SMP necropolis of Emilia. This type of ornament does not seem properly representative of the female

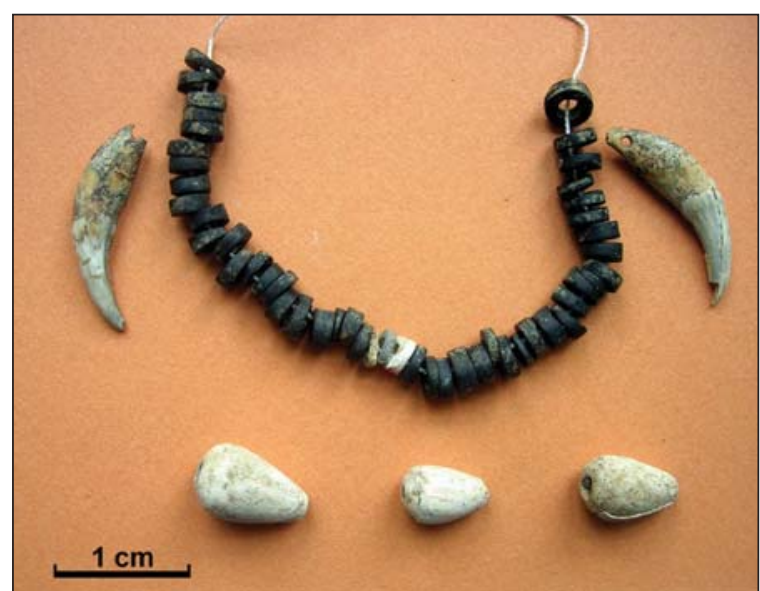

Fig. 18. Parma - via Guidorossi (grave 27): burial and composite necklace of an adult female formed by steatite and shell beads; two perforated fox canines and some Conus shells.

sphere, but its meaning can be linked to the ostentation of their male relatives' status.

Among wild species, the red deer is the most represented and evoked animal. Its antler and canines are very important hunting trophies. The antler may also be considered as a symbolic element representing regenerative power, since it changes every year, as an expression of the renewal of nature. Moreover, through its size, the antler expresses masculine strength.

\section{Analogies with other contemporary Neolithic groups}

To compare the SMP data with other contemporary Neolithic cultures in detail would go beyond the scope of our paper; nevertheless, it is worth mentioning some Middle Neolithic cases very similar to those of the SMP groups of Emilia (Fig. 27).

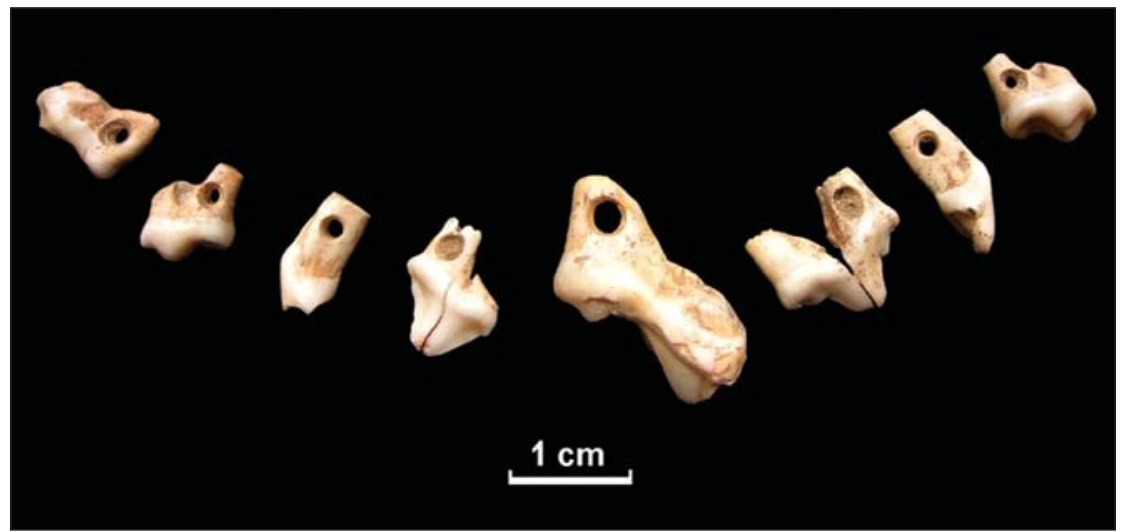

Fig. 19. Parma - via Guidorossi (grave 37): necklace of an adult female formed by one molar, three premolars, two canines and two incisors from a very old dog.

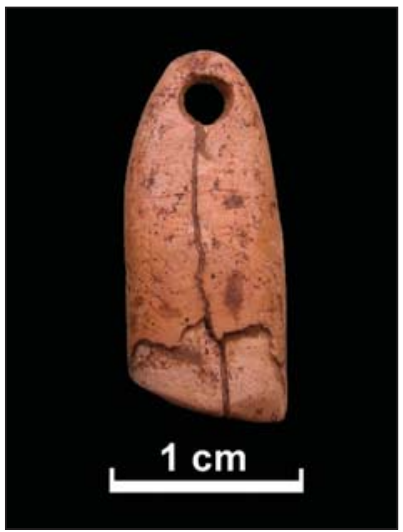

Fig. 20. Parma - via Guidorossi (grave 6): abraded perforated human canine. 

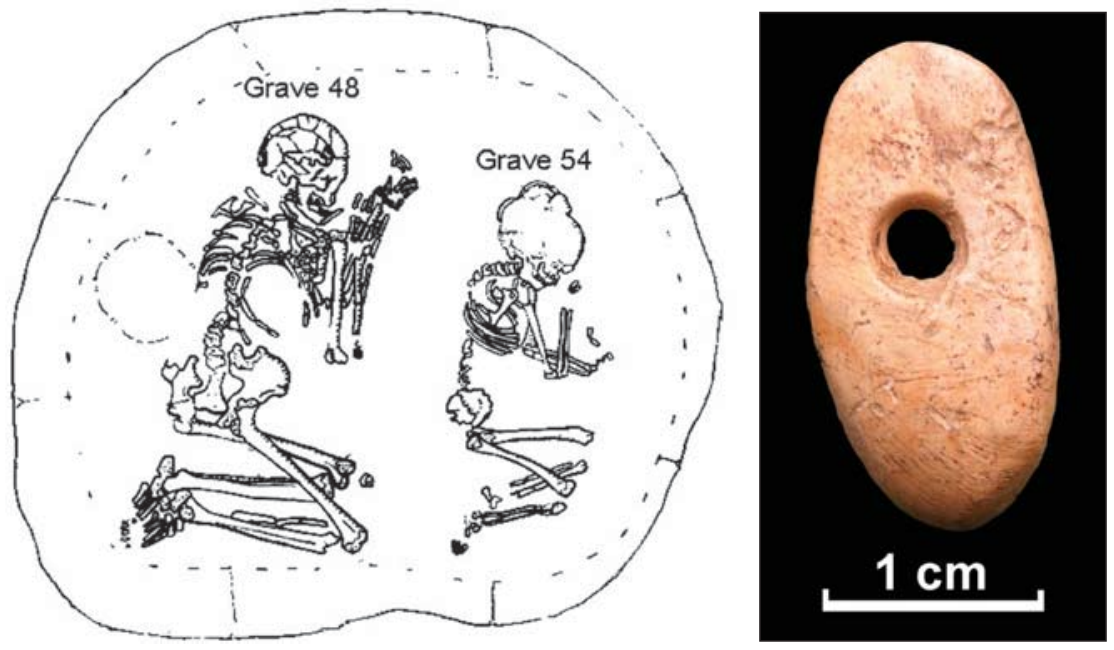

Fig. 21. Parma - Via Guidorossi (graves 48-54): imitation of a red deer canine worn by a female child associated with the burial of an old male.

With reference to dogs, from the Serra d'Alto culture there is evidence of dog depositions at the Cala Colombo Cave in Apulia, where a silo contained the disarticulate remains of two individuals and one complete young dog, while the remains of a second dog were spread in the upper deposit of the pit ( $\mathrm{Ge}$ niola 1974-76.210). Finally, we should note the very famous female and dog burials at Ripoli, in Abruzzi region (Parenti 1957). In such contexts, therefore, as in the SMP world, the dog has a twofold meaning, depending on its association with men or women: firstly, it is linked both in daily life and in the symbolic universe to the male and to hunting, where the dog is the hunter's friend and helps him catch prey; secondly, the dog is the animal of the domestic world when associated with the female as a protective guardian of the house. A special regard for dog in the ritual and mortuary sphere, sometimes associated with human burials, is also seen in Chassey culture in Rhone Valley (Beeching and Crubézy 1998.152-153), or in Vaucluse, Aude and HauteGaronne in southern France (Vaquer 1998.168).

In southern Italy, unlike in the SMP culture, domestic animal depositions and sacrifices in relation to burials or within ritual contexts, especially caves, is widely attested (Curci and Muntoni 2008; Manfredini, forthcoming). However, the evidence of the symbolic importance of red deer hunting comes from some sites of the Serra d'Alto culture in southern Italy, contemporary with SMP culture.

The Porto Badisco and Cosma caves in Apulia yielded very famous depictions, painted in black, of hunting scenes in which archers and dogs were represented together with abstract signs (Graziosi 1980;
Whitehouse 1992). Also of great relevance is the Manfredi Hypogeum of Santa Barbara (Geniola 1987; Whitehouse 1992) in the same region, where many deer skulls lined the sidewalls of one of its underground rooms with small middens of shells. Amongst the faunal remains found in the other room of the cave, the roe deer was the most common species. Some $60 \%$ of the faunal remains were of wild species; all the finds had been arranged during disposal, and carefully deposited and buried. Concerning the Serra d'Alto funerary contexts, it is interesting to mention the burial of a young man in the Scaloria Cave which contained a large antler as at Pontetaro and Arene Candide Cave (Tinè and Isetti 1982).

During the $5^{\text {th }}$ millennium calBC, birds, anatids in particular seem to play a very important role in rituals in central and southern Italian Neolithic cultures. The best known ritual context in which birds have been found is surely the Grotta dei Piccioni, ascribed to the Ripoli culture, where numerous anatid bones, with small balls of ochre and clay at one end, were found among the child burials and cremations (Cremonesi 1976). The representation of anatid heads often occurs in the shape of small handles on Serra d'Alto fine pottery. Also, at Serra d'Alto layers at Grotta del Kronio a small anatid-shaped head made of jadeite was found (Tinè and Tinè 1998).

The final point we wish to stress is the relevance of perforated teeth among the personal ornaments of the SMP groups. The use of perforated teeth as personal ornaments was common during the Middle Neolithic in Central Europe, especially in Hinkelstein, Grossgartach, Rössen, Stichbandkeramik and Lengyel groups. In these cultural spheres, red-deer, fox and wild cat teeth or

Fig. 22. Pontetaro settlement: steatite imitation of red deer canine.

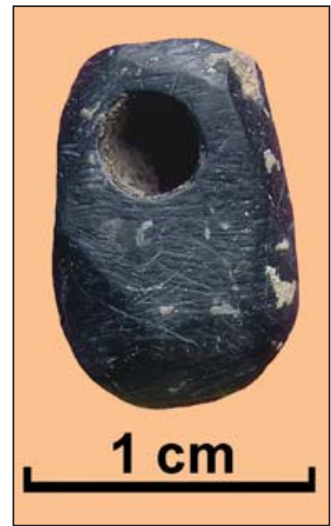




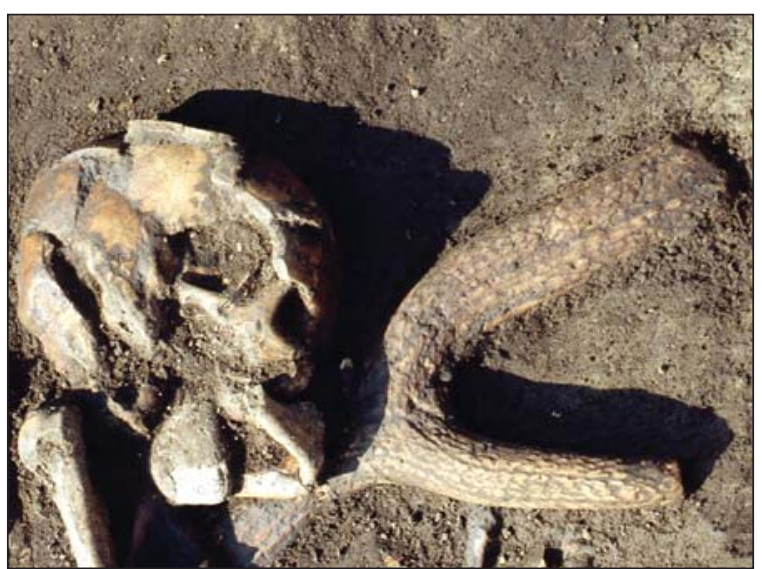

Fig. 23. Pontetaro (grave 1): red deer antler placed under the head of a mature male as offering.

wild boar tusks are preferred to perforated shells or Spondylus ornamental elements (Jeunesse 2002. $53,55)$. The occurrence of wild animal bone or antler artefacts is instead well documented for the Cerny culture in the Paris Basin (Sidera 1997; 2004), but in some ways could be reconducted to a common phenomenon of the Middle Neolithic as attested in Chassey culture (e.g. in the Camp de Chassey settlement - Thevenot 2005) or in the Serra d'Alto culture (e.g. in Grotta Pacelli - Striccoli 1988).

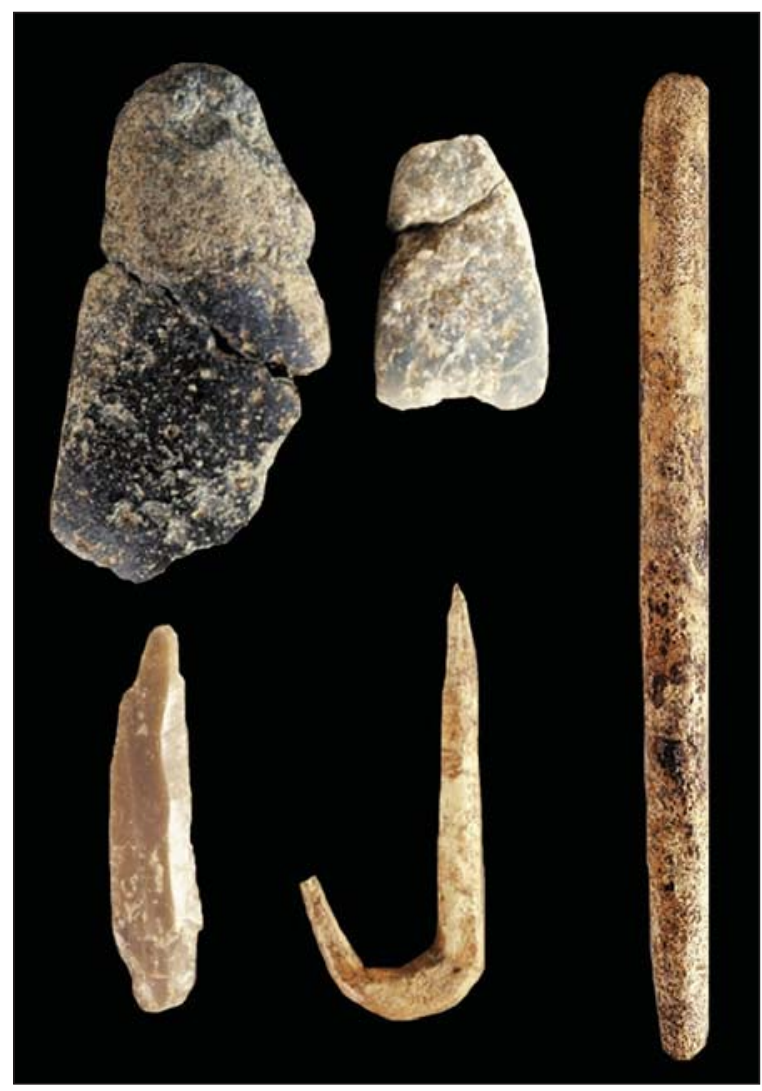

Fig. 24. Le Mose (grave 6): grave-goods of a mature male burial with red deer antler artefacts.
Some concluding considerations

The preference for perforated teeth or wild game bones does not necessarily arise from a simple aesthetic purpose, but can rather be seen as the result of a change among Middle Neolithic groups in the ideology pertaining to the social importance of hunting. In Italy, this fact seems related to a reduction in the consumption of game as food.

Hunting, once released from the requirements of everyday subsistence, becomes an ideal of virility taking roots in myth - the Mesolithic perceived as a mythical Golden Age? (Aurenche and Kozłowski 1999) - and participating in the creation of an Ideological World, as shown by the hunting scenes depicted in southern Italy

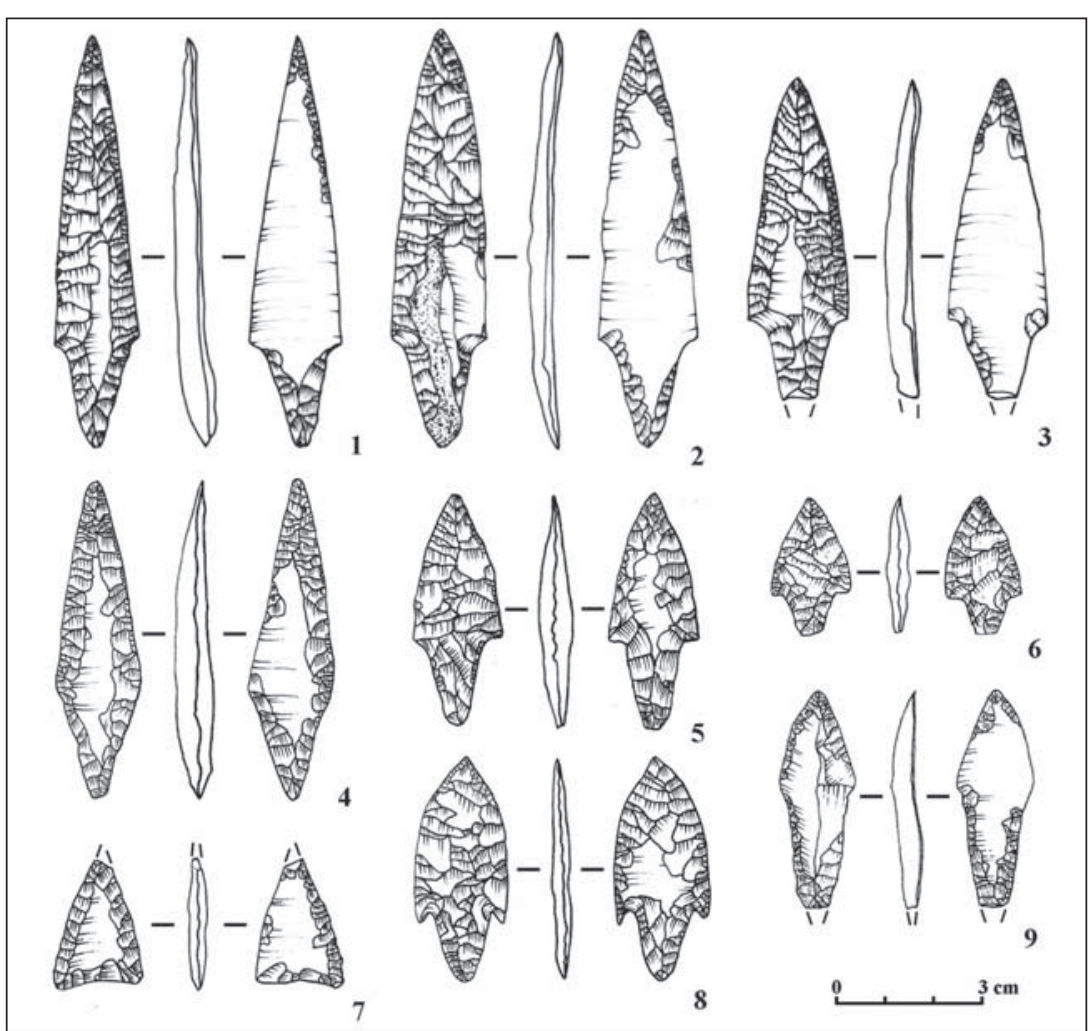

Fig. 25. Types of arrow-heads from SMP male burials of western Emilia. 1. Castelguelfo; 2.-3. Collecchio; 4.-5., 7.-8. Parma - via Guidorossi; 6., 9. Le Mose. 
caves. Also in death, the valour and the social role of a man is marked by the presence of objects referring to hunting, such as weapons, trophies and artefacts hinting at a particular game or prey.

Regarding the presence of dog, or dog remains, deposited near or in human burials, it is difficult to establish if this was simply related to the funerary ritual, as a sacrifice, or if the dog was given preferential post mortem treatment, similar to that of people, as a companion in many everyday activities. Dogs actually go hunting with men; they protect the domestic space and herds, etc. Not only because they are trained, but also due to a natural predisposition, they occupy an intermediate/liminal position between the human and the animal worlds. This close intimacy is well expressed by dog burials in or near human graves, so that the dog follows its master also in the death, to lead him in the unknown afterlife realm, as it usually helps him to move around in the wild, outside the domestic world.

The customs of SMP groups, like that of many other European Middle Neolithic groups, testify to the diffusion of a wild component in the form of hunting trophies, emphasizing also symbolically - the importance of the hunter's identity and his skill in killing wild animals in a society where subsistence actually depends primarily on domestic animals. There-

Fig. 26. Vitreous quartz arrow-head from the Pontetaro settlement.

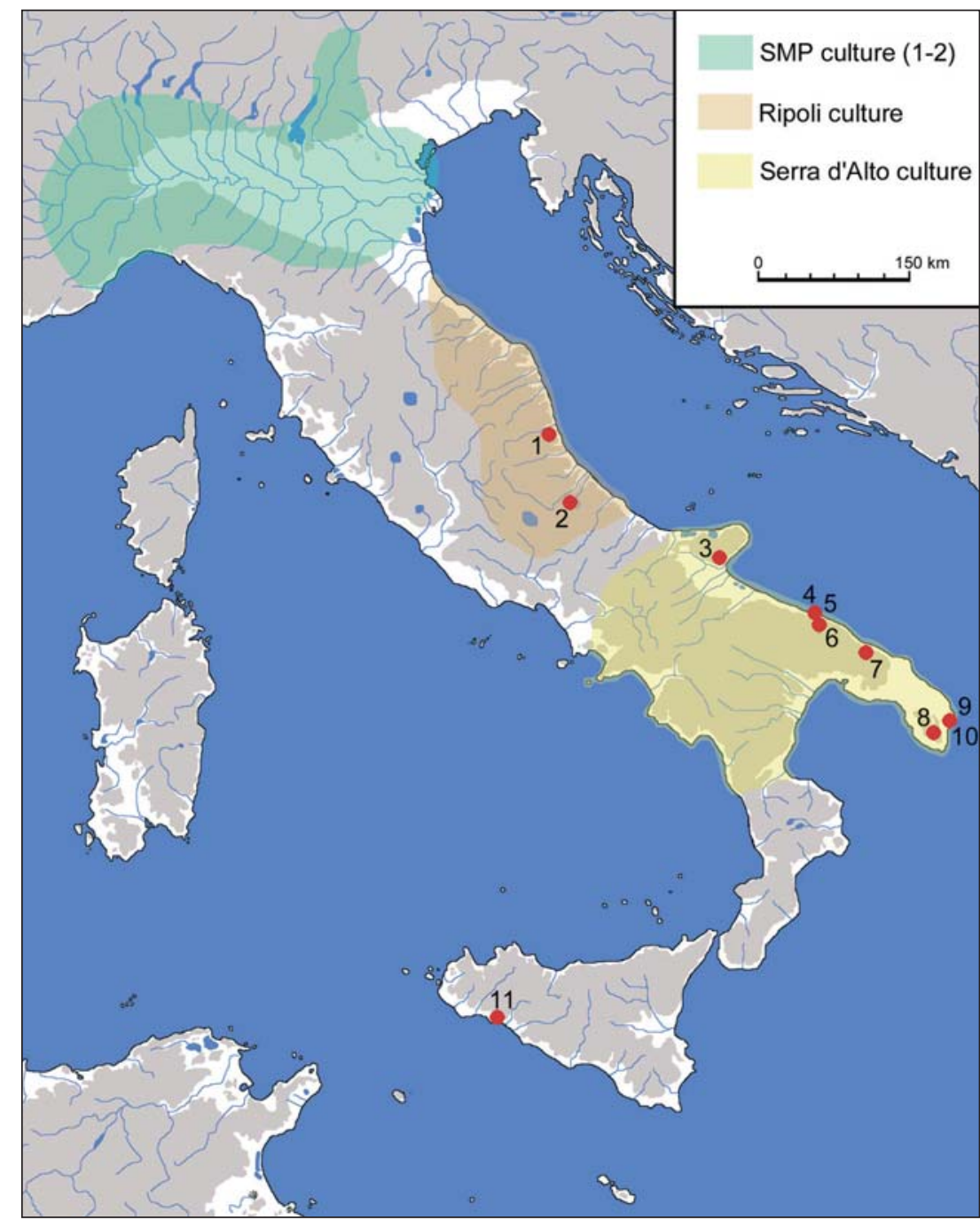

Fig. 27. Human-animal relation evidence and bird figurines from Italian Middle Neolithic sites: 1. Ripoli; 2. Grotta dei Piccioni; 3. Grotta Scaloria; 4. Grotta di Cala Colombo; 5. Ipogeo Manfredi di Santa Barbara; 6. Grotta Pacelli; 7. Grotta San Biagio; 8. Grotta della Trinitá; 9. Grotta di Porto Badisco; 10. Grotta Cosma; 11. Grotta del Kronio.

fore, a contrast arises between the funerary and ritual contexts and the domestic universe. The archaeological evidence tells us that there was a clear distinction between the daily round of subsistence activities of SMP people and their symbolic world, as represented by grave-goods and personal ornaments, and that some animals and weapons were chosen as symbolic agents to highlight this opposition. 


\section{REFERENCES}

AIMAR A. 1998. Analisi archeozoologica e tafonomica dei resti faunistici di Casalnoceto (Alessandria). In Preistoria e protostoria in Piemonte. Atti della XXXII Riunione Scientifica dell'Istituto Italiano di Preistoria e Protostoria (Alba, 29 settembre - 1 ottobre 1995). Firenze: 155-161.

AURENCHE 0., KOZŁOWSKI S.-K. (eds.) 1999. La Naissance du Néolithique au Proche-Orient ou le paradis perdu. Éditions Errance, Paris.

BAGOLINI B., BARFIELD L. H. 1971. Il neolitico di Chiozza di Scandiano nell'ambito delle culture padane. Preistoria Alpina 1: 3-74.

BAGOLINI B., BARFIELD L. H. and BROGLIO A. 1973. Ricerche nell'insediamento neolitico di Fimon-Molino Casarotto (Vicenza) (1969-1972). Rivista di Scienze Preistoriche XXVIII (1): 161-215.

BAGOLINI B., CORRAIN C., DALMERI G., LEONI M., NOVELLO A., PASQUALI T. and RIEDEL A. 1984. Il riparo di Moletta Patone di Arco nel Trentino meridionale. Preistoria Alpina 20: 103-146.

BAGOLINI B. 1990. Cultura dei vasi a bocca quadrata. Il sepolcreto de La Vela di Trento. In Die ersten Bauern, Pfahlbaufunde Europas, Band 2. Schweizerisches Landesmuseum, Zürich: 225-231.

1992. Il Neolitico dell'Italia settentrionale. In A. Guidi and M. Piperno (eds.), Italia preistorica. Laterza, Bari: 274-304.

BAGOLINI B., GRIFONI CREMONESI R. 1994. Il Neolitico italiano: facies culturali e manifestazioni funerarie. Bullettino di Paletnologia Italiana 85: 139-170.

BAILEY D. W. 2000. Balkan Prehistory. Exclusion, Incorporation and Identity. Routledge, London and New York.

BARFIELD L. H. 1970. La stazione neolitica de "la Vela" presso Trento. Considerazioni sulle tombe a cista nel Trentino-Alto Adige. Studi Trentini di Scienze Naturali 47: 35-55.

1971. Northern Italy before Rome. Thames and Hudson. London.

BARKER G. W. W. 1983. Neolithic subsistence in the central Po Plain. In P. Biagi, G. W. W. Barker and M. Cremaschi (eds), Casatico di Marcaria (Mantova) nel quadro paleoambientale ed archeologico dell'Olocene antico della Val Padana centrale. Studi Archeologici 2. Istituto Universitario, Bergamo: 45-67.
BAZZANELLA M. 2002. La fauna de La Vela: analisi preliminare. In Preistoria e Protostoria del Trentino-Alto Adige/Südtirol, in ricordo di Bernardino Bagolini. Atti della XXXIII Riunione Scientifica dell'Istituto Italiano di Preistoria e Protostoria (Trento, 21-24 ottobre 1997). Firenze, vol. I: 245-250.

BAZZANELLA M., MOSER L., MOTTES E. and NICOLIS F. 2002. I livelli neolitici del sito di Mezzocorona-Borgonuovo (Trento). Dati preliminari. In Preistoria e protostoria del Trentino Alto Adige/Südtirol, In ricordo di B. Bagolini. Atti della XXXIII Riunione Scientifica dell'Istituto Italiano di Preistoria e Protostoria (Trento, 21-24 ottobre 1997). Firenze, vol. I: 311-326.

BEECHING A., CRUBEZY E. 1998. Les sépultures chasséennes. In J. Guilaine (ed.), Sépultures d'Occident et genèses des mégalithismes. Éditions Errance, Paris: 145-164.

BERNABÒ BREA L. 1946. Gli scavi nella caverna delle Arene Candide (Finale Ligure), Vol. I. Bordighera.

1956. Gli scavi nella caverna delle Arene Candide (Finale Ligure), Vol. II. Bordighera.

BERNABÒ BREA M. 2006. Una statuina neolitica da una sepoltura VBQ a Vicofertile (Parma). Origini XXVIII: 37-47.

BERNABÒ BREA M., CULTRARO M., forthcoming. La statuetta femminile di Vicofertile (PR) nel contesto neolitico italiano e transadriatico: confronti tipologici e significati simbolici. In L'arte preistorica in Italia. Atti della XLII Riunione Scientifica dell'Istituto Italiano di Preistoria e Protostoria (Trento, 9-13 ottobre 2007).

BERNABÒ BREA M., MAZZIERI P., forthcoming. Oggetti e contesti rituali nella cultura VBQ dell'Emilia occidentale. Padusa XLIV.

BERNABÒ BREA M., MAFFI M., MAZZIERI P. and SALVADEI L., forthcoming a. Le necropoli VBQ in Emilia occidentale. Rivista di Scienze Preistoriche XL.

BERNABÒ BREA M., MAFFI M., MAZZIERI P., SALVADEI L. and TIRABASSI I., forthcoming $b$. Le necropoli VBQ in area emiliana. In M. Bernabò Brea, R. Maggi and A. Manfredini (eds.), 5000-4300 a.C. Il pieno sviluppo del Neolitico in Italia. Atti del convegno (Finale Ligure, 8-10 giugno 2009). Rivista di Studi Liguri.

BERNABÒ BREA M., MIARI M., BIANCHI P., GHIRETTI A., MICHELI R. and TIRABASSI I. 2006a. I manufatti litici d'adorno in Emilia tra neolitico ed età del Bronzo: tipologia, tecnologia, distribuzione. In Materie prime e scambi nella Preistoria italiana. Atti della XXXIX Riunione Scien- 
tifica dell'Istituto Italiano di Preistoria e Protostoria (Firenze, 25-27 novembre 2004). Firenze, vol. II: 697-712.

BERNABÒ BREA M., SALVADEI L., MAFFI M., MAZZIERI P., MUTTI A. and SANDIAS M. 2006b. Le necropoli VBQ dell' Emilia occidentale: rapporti con gli abitati, rituali, corredi, dati antropologici. In A. Pessina and P. Visentini (eds.), Preistoria dell' Italia settentrionale. Studi in ricordo di Bernardino Bagolini. Atti del convegno (Udine, 23-24 settembre 2005). Udine: 169-185.

BERNABÒ BREA M., SALVADEI L., MAFFI M., MAZZIERI P. and SANDIAS M. 2007. Les sépultures du Néolithique moyen de l'Emilie occidentale: rituels, rapports avec les habitats, données anthropologiques. In P. Moinat and P. Chambon (eds.), Les cistes de Chamblandes et la place des coffres dans les pratiques funéraires du Néolithique moyen occidental. Actes du colloques de Lausanne, 2006, Cahiers d'Archéologie Romande 110, Mémoire de la Société Préhistorique Française XLIII. Lausanne and Paris: 325-335.

BORRELLO M. A., MICHELI R. 2004. Spondylus gaederopus, gioiello dell'Europa preistorica. In M. A. Borrello (ed.), Conchiglie e Archeologia. Preistoria Alpina 40 (supplemento 1): 71-82.

BRONK RAMSEY C. 2010. on line http://c14.arch.ox.ac.uk/ oxcalhelp/hlp_contents.html consulted: 16 th April 2010.

CLASTRES P. 1966, L'arc et le panier. L'Homme 6 (2): 1331.

CASTAGNA D., GAZZONI V., BERRUTI G. L. F. and DE MARCH M., forthcoming. Studio preliminare sulle sepolture neolitiche del territorio mantovano: i casi di Bagnolo San Vito e San Giorgio. In M. Bernabò Brea, R. Maggi and A. Manfredini (eds.), 5000-4300 a.C. Il pieno sviluppo del Neolitico in Italia. Atti del convegno (Finale Ligure, 8-10 giugno 2009). Rivista di Studi Liguri.

CAUVIN J. 1997. Naissance des divinités, naissance de l'agriculture. La révolution des symboles au Néolithique. Éditions CNRS, Paris.

CAZZELLA A., CREMASCHI M., MOSCOLONI M. and SALA B. 1976. Siti neolitici in località Razza di Campegine (Reggio Emilia). Preistoria Alpina 12: 79-126.

CREMASCHI M., forthcoming. L'uso del suolo nel Neolitico in ambito padano. Lo stato dell'arte. In M. Bernabò Brea, R. Maggi and A. Manfredini (eds.), 5000-4300 a.C. Il pieno sviluppo del Neolitico in Italia. Atti del convegno (Finale Ligure, 8-10 giugno 2009). Rivista di Studi Liguri.

CREMONESI G. 1976. La Grotta dei Piccioni di Bolognano nel quadro delle culture dal Neolitico all'età del Bronzo in Abruzzo. Pisa.
CURCI A., MUNTONI I. 2008. Deposizioni rituali di animali nel Neolitico e nell'Eneolitico dell'Italia centro-meridionale. In F. D'Andria, J. De Grossi Mazzorin and G. Fiorentino (eds.), Uomini, piante e animali nella dimensione del sacro. Edipuglia, Bari: 47-62.

DEGASPERI N., MOTTES E., ROTOLI M. 2006. Recenti indagini nel sito neolitico de La Vela di Trento. In A. Pessina and P. Visentini (eds.), Preistoria dell' Italia settentrionale. Studi in ricordo di Bernardino Bagolini. Atti del convegno (Udine, 23-24 settembre 2005). Udine: $143-168$.

DE GROSSI MAZZORIN J., forthcoming. Le faune di alcuni siti VBQ emiliani. In M. Bernabò Brea, R. Maggi and A. Manfredini (eds.), 5000-4300 a.C. Il pieno sviluppo del Neolitico in Italia. Atti del convegno (Finale Ligure, 8-10 giugno 2009). Rivista di Studi Liguri.

DELFINO E. 1981. Liguria preistorica. Sepolture dal Paleolitico superiore all'età del Ferro in Liguria e nell'area ligure. Savona.

DEL LUCCHESE A. 1997. The Neolithic burials from Arene Candide Cave. In R. Maggi (ed.), Arene Candide: a functional and environmental assessment of the Holocene sequence (Excavations Bernabò Brea-Cardini 1940-50). Memorie 5. Istituto Italiano di Paleontologia Umana, Roma: 605-609.

DESCOLA P. 2004. Le sauvage et le domestique. Communications 76 (1): 17-39.

GENIOLA A. 1974-76. La comunità neolitica di Cala Colombo presso Torre a Mare (Bari): archeologia e cultura. Rivista di Antropologia LIX: 189-275.

1987. La Cultura di Serra d'Alto nella Puglia centrale. In Il Neolitico in Italia. Atti della XXVI Riunione Scientifica dell'Istituto Italiano di Preistoria (Firenze, 7-10 novembre 1985). Firenze, vol. II: 772-781.

GRAZIOSI P. 1980. Le pitture preistoriche di Porto Badisco. Origines. Firenze.

ISSEL A. 1908. Liguria geologica e preistorica. Atti della Società Ligure di Storia Patria XL.

JEUNESSE C. 2002. La coquille et la dent. Parure de coquillage et évolution des systèmes symboliques dans le Néolithique danubien (5600-4500). In J. Guilaine (ed.), Matériaux, productions, circulations du Néolithique à l'Age du Bronze. Éditions Errance, Paris: 49-64.

KENT S. 1989. Cross-cultural perceptions for farmers as hunters and the value of meat. In S. Kent (ed.), Farmers as hunters. The implications of sedentism. Cambridge University Press, Cambridge: 1-17. 
LAVIOSA ZAMBOTTI P. 1943. Le più antiche Culture agricole europee. L'Italia, i Balcani e l'Europa centrale durante il neo-eneolitico. Milano.

MAGGI R. 1997. The radiocarbon chronology. In R. Maggi (ed.), Arene Candide: a functional and environmental assessment of the Holocene Sequence (Excavations Bernabò Brea-Cardini 1940-50), Memorie 5. Istituto Italiano di Paleontologia Umana, Roma: 33-52.

MANFREDINI A., forthcoming. Animali, non solo cibo. In M. Bernabò Brea, R. Maggi and A. Manfredini (eds.), 50004300 a.C. Il pieno sviluppo del Neolitico in Italia. Atti del convegno (Finale Ligure, 8-10 giugno 2009). Rivista di Studi Liguri.

MARCHESINI M., GOBBO I. and MARTELLI S., forthcoming. La ricostruzione del paesaggio vegetale nel Neolitico medio nella Pianura dell'Emilia Romagna attraverso le indagini palinologiche. In M. Bernabò Brea, R. Maggi and A. Manfredini (eds.), 5000-4300 a.C. Il pieno sviluppo del Neolitico in Italia. Atti del convegno (Finale Ligure, 8-10 giugno 2009). Rivista di Studi Liguri.

MAZZIERI P., forthcoming. Il sito VBQ di stile "meandrospiralico" di via Guidorossi a Parma. In M. Bernabò Brea, R. Maggi and A. Manfredini (eds.), 5000-4300 a.C. Il pieno sviluppo del Neolitico in Italia. Atti del convegno (Finale Ligure, 8-10 giugno 2009). Rivista di Studi Liguri.

MAZZIERI P., BERNABÒ BREA M., forthcoming. Stilemi decorativi e significati simbolici nella decorazione vascolare VBQ. In L'arte preistorica in Italia. Atti della XLII Riunione Scientifica dell'Istituto Italiano di Preistoria e Protostoria (Trento, 9-13 ottobre 2007).

MAZZIERI P., GRIGNANO M., forthcoming. L'insediamento di VBQ I di Benefizio (Parma). In M. Bernabò Brea, R. Maggi and A. Manfredini (eds.), 5000-4300 a.C. Il pieno sviluppo del Neolitico in Italia. Atti del convegno (Finale Ligure, 8-10 giugno 2009). Rivista di Studi Liguri.

MAZZIERI P., MUTTI A., forthcoming. Il sito VBQ di Pontetaro (PR). In M. Bernabò Brea, R. Maggi and A. Manfredini (eds.), 5000-4300 a.C. Il pieno sviluppo del Neolitico in Italia. Atti del convegno (Finale Ligure, 8-10 giugno 2009). Rivista di Studi Liguri.

MICHELI R. 2004. Ornamenti in conchiglia del Neolitico dell' Italia settentrionale. In M. A. Borrello (ed.), Conchiglie e Archeologia. Preistoria Alpina 40 (supplemento 1): 53-70.

forthcoming. Ornamenti personali e gruppi neolitici: elementi di differenziazione culturale nell'ambito dei Vasi a Bocca Quadrata. In M. Bernabò Brea, R. Maggi and A. Manfredini (eds.), 5000-4300 a.C. Il pieno sviluppo del Neolitico in Italia. Atti del convegno (Finale Ligure, 8-10 giugno 2009). Rivista di Studi Liguri.
MORRIS B. 2000. The Power of Animals. An Ethnography. Berg. Oxford and New York.

MOTTES E. 2007. Spirali del tempo, meandri del passato: gli scavi archeologici a La Vela di Trento dal 1960 al 2007. Giunta della Provincia autonoma di Trento, Soprintendenza per i beni archeologici. Trento.

PARENTI R. 1957. Lo scheletro umano della "tomba del cane" a Ripoli (Teramo). Archivio per l'Antropologia e la Etnografia LXXXVII: 5-95.

PEDROTTI A. 1996. La pietra levigata nei corredi delle sepolture neolitiche dell'Italia settentrionale In Le vie della pietra verde. L'industria litica levigata nella preistoria dell'Italia settentrionale. Omega edizioni, Torino: 150163.

2001. Il Neolitico. In M. Lanzinger, F. Marzatico and A. Pedrotti (eds.), Storia del Trentino. La preistoria e la protostoria. Il Mulino, Bologna: 119-181.

PESSINA A., TINÈ V. 2008. Archeologia del Neolitico. L'Italia tra VI e IV millennio a.C. Carocci, Roma.

PETREQUIN A. M., PETREQUIN P. 1990. Flèches de chasse, flèches de guerre. Le cas de Danis d'Irian Jaya (Indonésie). Bulletin de la Société Préhistorique Française 87: 484-511.

REIMER P. J., BAILLIE M. G. L., BARD E., BAYLISS A., BECK J. W., BLACKWELL P. G., BRONK RAMSEY C., BUCK C. E., BURR G. S., EDWARDS R. L., FRIEDRICH M., GROOTES P. M., GUILDERSON T. P., HAJDAS I., HEATON T. J., HOGG A. G., HUGHEN K. A., KAISER K. F., KROMER B., MCCORMAC F. G., MANNING S. W., REIMER R. W., RICHARDS D. A., SOUTHON J. R., TALAMO S., TURNEY C. S. M., VAN DER PLICHT J., WEYHENMEYER C. E. 2009. IntCal09 and Marine09 radiocarbon age calibration curves, $0-50,000$ years cal BP. Radiocarbon 51(4): 1111-1150.

RIVERA A. 1999. La construction de la nature et de la culture par la relation homme-animal. In C. Calame and M. Kilani (eds.), La fabrication de l'humain dans les cultures et en anthropologie. Édition Payot, Lausanne: 49-72.

ROWLEY-CONWY P. 1997. The animal bones from Arene Candide. Final report. In R. Maggi (ed.), Arene Candide: a functional and environmental assessment of the Holocene Sequence (Excavations Bernabò Brea-Cardini 1940-50), Memorie 5. Istituto Italiano di Paleontologia Umana, Roma: 153-278.

RUSSELL N. 2002. The Wild Side of Animal Domestication. Society \& Animals 10 (3): 285-302.

SALZANI L. 1981. Preistoria in Valpolicella. Verona. 
SIDERA I. 1997. Le mobilier en matières dures animales en milieu funéraire Cerny: symbolisme et socio-économie. In C. Constantin, D. Mordant and D. Simonin (eds.), La Culture de Cerny. Nouvelle économie, nouvelle société au Néolithique. Actes du Colloque International de Nemours, 1994. Mémoires du Musée de Préhistoire d'Ile-deFrance 6: 499-513.

2004. De l'usage des produits de la chasse pour différencier des hommes. Fonction votive et sociale de la chasse au Néolithique ancien et moyen du Bassin parisien. In P. Chambon and J. Leclerc (eds.), Les pratiques funéraires néolithiques avant 3500 av J.-C. en France et dans les régions limitrophes. Mémoires de la Société Préhistorique Française XXXIII: 91-98.

STARNINI E., VOYTEK B. 2005. Bancole (Porto Mantovano, Mantova): aspetti tipologici e funzionali di un'industria litica della prima fase della Cultura dei Vasi a Bocca Quadrata in Val Padana Centrale. In F. Martini (ed.), Askategi miscellanea in memoria di Georges Laplace. Rivista di Scienze Preistoriche (supplemento 1): 395-419.

STRICCOLI R. 1988. Le Culture preistoriche di Grotta Pacelli (Castellana Grotte-Bari). Schena. Brindisi.

THEVENOT J.-P. (ed.) 2005. Le camp de Chassey (Chasseyle-Camp, Saône-et-Loire). Les niveaux néolithiques du rempart de «la Redoute». Revue Archéologique de l'Est 22.

TILLEY C. 1996. An ethnography of the Neolithic. Early prehistoric societies in southern Scandinavia. Cambridge University Press, Cambridge.

TINÈ S., ISETTI F. 1982. Culto neolitico delle acque e recenti scavi nella Grotta Scaloria. Bullettino di Paletnologia Italiana 82: 31-70.

TINÈ S., TINÈ V. 1998. La Sicile. In J. Guilaine (ed.), Atlas du Néolithique européen, II: L'Europe occidental. Liège: 133-163.

TURNER V. 1967. The forest of symbols. Aspect of Ndembu ritual. Ithaca-London. Cornell University Press.

VAQUER J. 1998. Les sépultures du Néolithique moyen en France méditerranéenne. In J. Guilaine (ed.), Sépultures d'Occident et genèses des mégalithismes. Éditions Errance, Paris: 165-186.

WHITEHOUSE R. D. 1992. Underground Religion. Cult and Culture in Prehistoric Italy. Accordia Research Centre. University of London. London.

WILLIS R. 1974. Man and Beast. Paladin. London.

\section{back to CONTENTS}

